\title{
¿QUÉ HACEMOS JUGANDO MAL CON LAS CARTAS DE LA EDUCACIÓN, MIENTRAS VAMOS EN UN CAMAROTE DEL TITANIC?
}

\section{WHAT DO WE DO PLAYING BAD WITH THE LETTERS OF EDUCATION, WHILE WE GO IN A TITANIC CABIN?}

\section{Agustín de la Herrán Gascón}

Universidad Autónoma de Madrid

https://orcid.org/0000-0001-9156-6971

\section{"Jugar con lo existencial, pero vivir en lo esencial"}

(manu gascón hernández)

\footnotetext{
$1 \quad$ Herrán Gascón, A. de la (2019). ¿Qué hacemos jugando mal con las cartas de la educación, mientras vamos en un camarote del Titanic? En A. de la Herrán, J. M. Valle y J. L. Villena (Coords.), ¿Qué estamos haciendo mal en la educación? Reflexiones pedagógicas para la investigación, la enseñanza y la formación (Págs. 331-391). Barcelona: Octaedro.
}

\section{RESUMEN}

El objetivo de este ensayo es responder a la pregunta 'qué estamos haciendo mal en la educación'. Para ello se ha recurrido a un diagnóstico pedagógico ensayístico de carácter evaluativo de la propia educación, orientado a percibir y analizar causas, errores, insuficiencias, parcialidades, sesgos, etc. Los resultados son observaciones realizadas desde la Pedagogía radical e inclusiva. Con estas indagaciones no 
se pretende convencer a nadie, sino recorrer un camino en el que razonar sin temor, no filosóficamente, sino pedagógicamente, es decir, tomando como referencia la educación y la formación.

\section{PALABRAS CLAVE}

Educación, formación, conciencia, Pedagogía radical e inclusiva

\section{SUMMARY}

The purpose of this essay is to answer the question 'what are we doing wrong in education'. For him it was resorted to an educational essay diagnosis of an evaluative character of the proper education, oriented to understand and analyze causes, errors, insufficiencies, partialities, slanting, etc. The results of the observations made since radical and inclusive pedagogy. With these inquiries, it is not intended to convince nadie, but to resort to a path in which to reason without fear, not philosophically, pedagogically, to decide, taking as reference the education and training.

\section{KEY WORD}

Education, training, awareness, radical and inclusive pedagogy

\section{INTRODUCCIÓN}

¿De qué sirve teclear correctamente un número en el teléfono mientras se conduce, si nos salimos de la carretera? ¿De qué vale hacer las cosas bien, si vamos en un camarote del Titanic? ¿No será que se precisa profundizar más en lo que se hace -o se cree que se hace- bien o mal, para diferenciar entre creencia y fenómeno? ¿No será que la atención se tiende a poner en lo accesorio, y no en lo fundamental? ¿No tendrá algo que ver con ello nuestra formación?

Las preguntas fundamentales de una acción consciente son: a dónde vamos, cómo lo hacemos, a qué velocidad, quién conduce, cuál es su estado de salud y formación, qué estamos haciendo, qué estamos construyendo bien o mal, qué estamos dejando de hacer y construir; por qué avanzamos, para qué lo hacemos, cómo vivir con más conciencia, quién se hace estas preguntas, cuáles sobran, faltan...

El objetivo de este ensayo es responder a la pregunta 'qué estamos haciendo mal en la educación'. Para ello se ha recurrido a un diagnóstico pedagógico de carácter evaluativo de la propia educación, orientado a percibir y analizar causas, errores, insuficiencias, parcialidades, sesgos, etc. Los resultados son observaciones, cuya fiabilidad se ha confirmado durante veinticinco años. Desde ellas no se pretende convencer a nadie, sino recorrer un camino en el que razonar sin temor, no filosóficamente, sino pedagógicamente, es decir, tomando como referencia la educación y la formación.

Para ello se ha ido más allá de la normalidad educativa, cuya recurrencia limita la renovación pedagógica y el cambio del cambio educativo (Herrán, 1993, 1996, 2013). Con la formación disponible, se ha intentado observar la educación de forma extraña, como si se desconociese. El descubrimiento progresivo ha llevado a lo que se refleja o relata.

Cuesta ver y admitir que, quizá, desarrollemos una educación radicalmente equivocada (Herrán, 2017a, 2017c), y que sea el efecto lógico de una sociedad dormida y desorientada. Deducirlo requiere distanciamiento inicial, duda intermedia y humildad final. Esta triple competencia no abunda en el mar de miopía educativa en que vivimos. Nosotros también somos miopes. Por eso observaremos el fenómeno desde el enfoque "radical e inclusivo de la educación o la formación" (Herrán, 2014a, 2016c, 2017c), con énfasis en la comprensión radical. 
Esta perspectiva sostiene que nuestra educación es, a priori, superficial y exteriorizante, necesaria e insuficiente y globalmente incompleta, porque, en general, no se razona desde la conciencia. Este mal hábito de la razón lleva, entre otros comportamientos, a invertir la realidad, y a llamar océano al oleaje y profundidad a la superficie. Congruentemente, como el árbol de la educación se identifica sólo con su parte visible, se suele llamar raíz al tronco, a las ramas, a las flores, a los nidos..., y de la verdadera raíz nada se sabe, porque ni nos acordamos de su presencia.

En educación se ve poco, apenas la porción sobresalida, de modo que lo que se denomina realidad pedagógica se identifica con lo que se conoce y no con lo que es y, menos, con lo que podría llegar a ser. Este hecho, complejo y obvio, que ocurre individual y socialmente, o no se reconoce o se niega. Un efecto es que lo radical, lo enterrado no se incluye en el campo visual de la educación, de modo que, a todas luces, no existe. Si se admitiese, se colegiría que la educación es profundamente incompleta, hasta el punto de no poderse llamarse 'educación', porque su parte más vital, que sostiene y nutre a todo el ser, ha sido omitida, negada, excluida de la normalidad occidental o globalizada, por un condicionamiento de siglos. Nos referimos a constructos claves capaces de articular retos educativos y pedagogías renovadoras, como el ego humano, la conciencia humana, el autoconocimiento, la muerte, la humanidad, la universalidad, el amor, la meditación...

Paradójicamente, estas necesidades educativas no demandadas no son extrañas a algunos profesores $e$ investigadores aislados que intuyen o entienden que la acción educativa es susceptible de otras lecturas comprensivas más hondas y amplias. Se intuye entonces que, si hay árbol, hay raíces interiores, eso sí, mal conocidas e invisibles a los ojos, porque las raíces están presentes en cualquier parte del ser.
El problema epistemológico general y epistémico particular de lo que nos ocupa es que algunas observaciones que siguen no son asimilables a conocimientos de la ciencia normal de la educación (campo) o de la Pedagogía (ámbito científico) y de otras Ciencias de la Educación, o a lo habitualmente entendido. Por eso, porque los conocimientos previos pueden ser la mayor barrera para la admisión de otras formas de ver la realidad, puede que lo que sigue se rechace, no se admita, no se quiera entender, no guste $o$ se ningunee en bloque. Contamos con ello, porque será lo normal y, quién sabe, si lo conveniente hoy. Esto ha ocurrido en las ciencias cuando las aportaciones teóricas o empíricas han perturbado la homeostasis de la ciencia estándar.

\section{DIAGNÓSTICO PEDAGÓGICO RADICAL}

\section{El paradigma del Titanic}

El Homo sapiens sapiens, definible por lo poco que cree que sabe que sabe, conforma una sociedad que no es la del conocimiento, sino de la ignorancia no reconocida. Desde este referente, anhela un ser humano competente e instrumentalmente actualizado (Homo sapiens sapiens tecnologicus), por encima del consciente (Homo sapiens sapiens ignorans). Aún no ha resuelto esta dualidad hacia la síntesis.

En la fase actual, su educación primaria, secundaria y la mal llamada 'educación superior' -que sólo es 'posterior', cuando llega a ser 'educación'-, lo buscan a toda costa, planificada y compulsivamente a la vez, sobre enfoques de programación competenciales. Desde un punto de vista radical e inclusivo, el Homo sapiens sapiens tecnologicus es una incompatibilidad formativa o una 'cima de la evolución' descompensada y ficticia.

Responde a una dinámica social, profesional y educativa que comparte características con el legendario hundimiento del Titanic: 
- Adolece de egocentrismo y narcisismo: parte de la conclusión anticipada (tácita o sonora) de que, en ese sentido, nuestra forma de vida va bien, porque es 'omnipotente', luego 'insumergible'.

- Se construye con una educación aparente e incompleta: aun en los casos en que se pueda calificar como 'excelente', es rudimentaria e inconclusa. Algo parecido le ocurrió al Titanic, cuyo casco se construyó con acero de mala calidad: con exceso de azufre y fósforo y con carencia de manganeso. La política de la rentabilidad y la reputación fue su opción. Pero antes lo fue la de la falta de ética o de conciencia.

- Avanza a alta velocidad y aceleradamente: la serenidad se pierde y, en su lugar, la sensación de aruosal se experimente tanto a nivel personal como colectivo. La prioridad, como decía Machado (2008), es 'hacer camino al andar'. El hacia dónde vamos parece secundario, mientras la nave va. $Y$ del sentido a largo plazo, ni se habla, quizá por tres razones: por miopía, porque la conciencia de humanidad es inexistente o muy lábil y porque su toma de conciencia pudiera interferir con los pequeños intereses egocéntricos e inmediatos.

- Marcha sin importar quién pilota la nave: su visión, su inmadurez, su formación, su salud, etc. son aspectos en los que no se piensa. En el caso del recordado navío era un excelente capitán a punto de jubilarse. Por tanto, estaba en la cima de su experiencia profesional y personal; era un mejor imposible formativo a priori, salvo por su ego y su conciencia. ¿Qué Pedagogía incluye el ego y la conciencia como constructos formativos fundamentales para el capitán del Titanic? Las respuestas son asimilables a las de otros temas radicales, porque esta formación de dirigentes es también otro reto educativo radical. Hoy, en nuestra 'predemocracia' (Herrán, 2003), prima el voto, que no siempre se otorga en función de la formación del/la líder o dirigente. ¿Quién piensa que la formación de dirigentes -al hilo de la practicada en la China de Lao Tse (2006) o de Confucio (1969)-, con énfasis en el ego y la conciencia, es fundamental? (Herrán, 2003)?

- Se confía en la propia visión, que se entiende como válida: Se construye sobre lo que se ve, que es poco y sin horizonte más allá del ego, añadiendo que a la parte que se ve se llama 'todo'. En el tiempo del Titanic, no había radar -no se había inventado aún-, pero tampoco prismáticos, porque se olvidaron en un armario bajo llave. El miope ve bien, pero sólo de cerca.

- Se desoyen las advertencias ajenas: En la sociedad del egocentrismo, la autocrítica y la rectificación brillan por su ausencia. Se admite que haya personas más altas o más flexibles que otras. Pero no que vean más que otras. Enfocarse sobre todo en uno mismo, es vivir desenfocado. En el episodio del Titanic, otros barcos que divisaron bloques de hielo por la zona y alertaron. Esto se comunicó al capitán, que hizo oídos sordos; quizá no era asimilable a la tesis de la omnipotencia y la insumergibilidad, quizá divisó alguno menor. Pero ninguno es sólo lo que asoma.

- Se ha cimentado con premisas clasistas: El enfoque está construido a la medida de los países del 'primer mundo', y dentro de ellos, con el referente de los profesional y tecnológicamente competentes. Esta diversidad favorece más a unas clases de personas que a otras. El pasaje del Titanic estaba clasificado. Cuando se hundía, se procedió al salvamento de forma caótica y clasista. Los botes sólo estaban destinados a unos pocos, y éstos no eran la generalidad. Quizá por eso se habla tanto de inclusión 
y de educación democrática en nuestra sociedad: porque el sustrato es excluyente, racista, sexista, Igbifobo, parcial... Si se atendiera el substrato, y no sólo lo aparente, quizá se observaría que sobra ego y falta conciencia a nivel de humanidad $y$, en general, en sus subsistemas, incluidas las personas.

Cada conciencia personal o sistémica pilota su nave. Lo prioritario es la duda hacia uno mismo. La velocidad y ni siquiera el sentido son prioridades, en la medida que pueden ser efectos de la conciencia. A partir de ello, lo esencial es ver. O sea, vernos para ver después lo demás. Por ello, lo más urgente es el quietismo, el encastillamiento del capitán del Titanic -porque toda omnipotencia oculta una impotencia-, darnos cuenta de que vemos poco y mal, por nuestro estado de sueño, de egotización, de desequilibrio y de deformación relativas. Posteriormente, se tratará de ver de otro modo o con otra conciencia el mar, la ruta de navegación, los icebergs, el horizonte, las advertencias de otros, la tripulación, los pasajeros, etc.

En la actualidad la responsabilidad de la navegación radica en quien aporta visión y orientación a la nave (dirigentes, controladores, vigías, radares...). Socialmente, la responsabilidad de lo que ocurre o deja de ocurrir en la educación es, en primera instancia, de la universidad y de sus investigadores, por su imperativo evaluativo para el cambio social en sus ámbitos de conocimiento. En segunda instancia, de la propia sociedad, de su receptividad, de su escucha. Si, por su formación insuficiente, tiende a considerar sólo los hallazgos potencialmente rentables, si no atiende las alertas, nos pasará como al Titanic. Pero, sobre todo, depende de cada conciencia.

Empezamos este escrito preguntándonos dos cuestiones: '¿De qué vale hacer las cosas bien, si vamos en un camarote del Titanic?' y si ‘¿No será que en ambos casos la atención se ha puesto en lo accesorio, y no en lo fundamental?'. Lo fundamental no es tener conciencia de viajar en el Titanic, sino otras dos cosas relacionadas, pero distintas: una es saber que el Titanic somos cada uno de nosotros -cada persona-, aunque lo cómodo sea pensar en el planeta Tierra, en un país, en un ismo, en un sistema formal o informal de pertenencia... La segunda es que lo grave es navegar en un camarote, o sea, en una caverna o más (Platon, 1969). Vivir en cavernas, ignorar o querer entender condicionado por ellas: ése es el error radical del que provienen los demás.

\section{El error socrático}

Sócrates y su diálogo son una fuente clave de la Pedagogía, la Filosofía y las metodologías de enseñanza activas. La sociedad globalizada autocalificada como del conocimiento, hunde también sus primeras raíces históricas e innovadoras en Sócrates.

Al mismo tiempo, muchos científicos, filósofos y pedagogos se definen como presocráticos, en sentido estricto, porque no han interiorizado lo esencial del legado del educador griego, que coincidió con una enseñanza anterior de Confucio (1969), y que convergía en la conciencia de la propia ignorancia como factor del verdadero saber.

Sócrates fue un sabio, pero no un maestro de conciencia, como sí lo fueron Lao Tse (2006) o Siddhartha Gautama (Buda, 1997; Osho, 2007). Aunque Sócrates (en Platón, 1969) habló de autoconocimiento, no explicó cómo, algo que sí hizo Gautama buda. Sócrates no resistiría una comparación con el primer buda.

Por afinidad cultural y geográfica, Occidente siguió a Sócrates y ordeñó su ubre hasta la deformación y la infección. La clase de educación que generó su tradición, mezcla de leche y de pus, es 'nuestra educación'. Su base es el aprendizaje y el conocimiento 
y, desde ellos, los saberes, competencias, emociones, personalidades y, en todo caso, en una conciencia periférica aplicada, bien al saber, bien al desconocimiento del saber. Apenas ha superado la profundidad del diálogo socrático. En definitiva, se apoya en lo exterior de lo interior del ser humano, en su periferia. Lo interior de lo interior permaneció y permanece en gran medida inédito. Al seguir a Sócrates y, tras él, a la Filosofía occidental, lo esencial permaneció inédito e inexplorado para la educación y para la Pedagogía, cuya orientación fue y es hoy sobre todo exteriorizante. Desde luego, las religiones monoteístas y sus sistemas enredadores, boleros y ritualistas que se arrogaban la interiorización, tampoco educaron jamás en este nivel, porque se contradirían; más bien confundieron y adoctrinaron en la estafa y en la invención ad hoc, y así siguen.

Queremos pensar que la futura sociedad de la conciencia o de la formación se enraizará en la enseñanza de los pocos maestros despiertos (Lao Tse, 2006; Buda, 1997; Lie zi, 1987; Zhuang zi, 1999, etc.), que mucho tienen en común con la de los pueblos originarios y con la enseñanza natural del niño muy pequeño (Herrán, 2015c). Sus enseñanzas tienen, precisamente, lo que la educación basada en el saber, con base en Sócrates, no ostenta. De hecho, de Lao Tse y de Siddhartha Gautama proviene lo que podría describirse como 'educación o formación con base en el no saber', esto es, en la pérdida, la conciencia y meditación. Su educación es para despertar. De ellos surge la posibilidad de enriquecer o completar radicalmente la Pedagogía y la educación habituales.

Sócrates fue una inteligencia muy brillante, un extraordinario ser humano, pero no fue un buda, de acuerdo con lo que se sabe de su vida y su enseñanza. Por eso hemos propuesto, como directriz epistemológica para la Pedagogía de mañana, trabajar en los fundamentos para una Pedagogía no dual, esto es, basada en el saber y, además, en el no saber (Herrán, 2018b). ¿Cabe una compatibilidad mayor, cuando lo que una tiene a la otra le falta? Desde un símil metodológico, se trataría de unir el diálogo socrático y la meditación, el conocimiento y la conciencia, lo exterior y lo interior. Se trata de sincronizar las dos alas para poder volar, porque, quizá elevarse en complejidad de conciencia, sea lo propio ser humano, lo que puede sintetizar su posible evolución.

Sin embargo, esta síntesis no se lleva a cabo. Hay un condicionamiento de siglos motivado por el ego de Occidente (occidentalismo) que impide vaciar la propia taza para llenarse de otras formas de entender la realidad, en este caso, la educación, la formación. ¿Por qué no se hace, no ya en los departamentos o facultades de Pedagogía, de educación o de formación de profesores o de educadores, ni siquiera en los sistemas educativos o en los centros docentes, sino en el interior de cada ser humano?

Una respuesta viene dada por la observación del contexto. Hemos observado que no estamos en la sociedad del conocimiento, y menos aún en las siguientes sociedades de la conciencia o de la educación, a las que podríamos apuntar y dirigirnos. Estamos en la sociedad del acceso a la información sesgada (o de la ilusión informativa) -los pocos que lo están-, de la ignorancia no reconocida, del egocentrismo y la inmadurez generalizada. Como consecuencia de ello, quizá, no es que no haya voluntad para la convergencia entre los maestros de Oriente y de Occidente, es que 'no se quiere querer' que ocurra. Sin embargo, se podría dar pasos de gigante en lo que a educación se refiere, porque se pasaría, desde la síntesis de fundamentos de una educación basada en el saber y en el no saber, de una educación incompleta a una educación de primera división.

El 'error de Sócrates' no es atribuible al educador ateniense. La culpa no la tiene nadie. La causa, en cambio, no está en la voz, sino en los ecos, 
y cuaja en progresión creciente. Dicho de otro modo, a medida que se avanza en complejidad de ego a la par que de conciencia, ese error es más nuestro que de Sócrates. Él trascendió en la historia. Nosotros nos hemos quedado deslumbrados por el brillo de Sócrates, y eso ha limitado la evolución de la educación.

Con sus premisas y su metodología, no es posible llegar al final de la educación o de la formación o a la educación plena. Nos quedamos a mitad de camino o antes, y a ese punto le llamamos, quizá, 'máximo desarrollo de capacidades'. Es un error: ni es el máximo, ni las capacidades están en el centro de la educación. La identificación de la educación con el aprendizaje, el conocimiento-saber y la acción-práctica-capacidad para resolver problemas es como identificar a una persona con su respiración, con sus extremidades y con su capacidad para desplazarse: es algo muy incompleto y sin sentido objetivo, fenoménico, aunque lo repitan todos los sistemas educativos $y$ todos los organismos internacionales de educación del orbe.

Mientras que los cimientos de la Pedagogía y del resto de ciencias de la educación sigan tan superficiales, seguiremos cometiendo este error, por lo que la educación será engañosa o y se deslizará sobre el futuro como un trineo sin timón, desgastándose y nublándose por el camino.

\section{La violencia procústea en la educación}

Se trata de completar la educación para entenderla cabalmente. Como no se comprende, se violenta. Desde el enfoque radical e inclusivo, lo que se observa es que, en general, "La educación es una forma de violencia” (Herrán, 1993). Con más detalle, lo que se percibe es que la educación en cada sistema social y en cada ser está funcionalmente amputada por su parte radical y estirada e hipertrofiada por su parte emergida. Dicho de otro modo, es objeto de 'violencia procústea'.

Según la mitología griega, Procusto fue un hijo de Poseidón. En algunas versiones, era un gigante. Casado con Silea, fue padre de Sinis. Su nombre viene del griego antiguo Прокрои́бтns Prokroústês. También fue conocido como Procrustes, 'estirador', Damastes, 'avasallador', 'controlador', Polipemón, 'muchos daños' o Procoptas. Procusto era un posadero. Vivía en una cueva en unas colinas a las afueras de Ática o Eleusis -según la versión-. Era un lugar retirado y de paso. Ofrecía posada al viajero solitario. Le daba conversación y de comer, y luego, le invitaba a descansar en una de sus camas de hierro. Procusto tenía dos camas: una grande y otra pequeña. Cuando el viajero dormía, le ataba a las cuatro esquinas de la cama, le inmoviliza y le amordazaba. Si su cuerpo era de mayor longitud que la cama, amputaba lo que sobresalía con una sierra: manos, pies, cabeza... Si era más corto, lo descoyuntaba a martillazos y estiraba las extremidades hasta alcanzar las medidas de la cama. Tras las mutilaciones o los alargamientos, ninguno de los huéspedes de Procusto pudo caminar o vivir. Finalmente, su hermano Teseo le detuvo. En su viaje de Trecén (Peloponeso) a Atenas, se topó con Procusto y le desafió a comprobar si su propio cuerpo encajaba con el tamaño de su cama. Cuando se tumbó, Teseo le ató a la cama y le amordazó, como él hacía con los viajeros. Allí le amputó los pies y la cabeza.

Del mito a la realidad. Por un lado, se alude a 'lecho de Procusto' o a 'cama de Procusto' cuando se fuerza a la aceptación exacta a una norma arbitraria. En ciencia, se aplica a la deformación de los datos de la realidad para que se ajusten a una hipótesis falaz. A esta premisa funcional responden los adoctrinamientos y sus ismos, al contrario que la verdadera ciencia, que se construye desde la duda, la conciencia de ignorancia y el diseño de investigación, que 
permitirán generar conocimiento válido y fiable. Así mismo se habla de 'error procústeo', por ejemplo, en Ergonomía, para conceptualizar lo anti ergonómico, o sea, cuando el usuario se tiene que adaptar a los objetos, no al revés.

Desde la educación -incluida la 'educación durante toda la vida'- se comete 'violencia procústea' de diversos modos, eso sí, sin apercibirse de ello, sin cometer delito reconocido, ni por ella, ni por el entorno social. Nos explicamos: las sociedades egocéntricas, sus sistemas de educación o los organismos internacionales de educación, como sujetos, serían Procusto. Los educandos de cada lugar y de cada momento histórico, los centros docentes, los profesores y a veces los investigadores, serían los viajeros. Los sistemas y centros educativos serían, además, las posadas. Las camas de Procusto podrían ser los niveles de enseñanza y, después, los puestos de trabajo.

¿Qué hace la educación en los viajeros? Por un lado, les nutre y les da fuerzas, pero con una educación sólo basada en competencias, en aprendizajes y en otros conocimientos, les sodormece, tanto en la formación inicial como en la continua. Tras nutrirles, les disloca y alarga, o les mutila. Lo habitual es que haga las dos cosas.

¿Por qué lo hace? Porque no comprende con claridad aquello a lo que se refiere: qué es la educación, la formación. Actúa conforme lo entiende y se demanda, y estos son dos criterios lábiles: por un lado, lo educativo no se entiende. Por otro, se priorizan intereses no pedagógicos (económicos, culturales, nacionalistas, religiosos, etc.). Un resultado es que a cualquier cosa se ha llamado educación. 'Educación' acaba por significar 'lo que vía aprendizaje es imprescindible para la supervivencia y desarrollo de mi sistema'. Desde fuera, 'la educación' se interpreta como un ámbito fluido, camaleónico y maleable.
Desde un punto de vista científico, la educación es un ámbito que no parece investigable con rigor. De ahí algunas críticas a la Pedagogía como ciencia, si bien suelen realizarse desde una intensa y no reconocida ignorancia. Realmente, es justo al revés: la educación, la enseñanza y la formación precisan de una investigación pedagógica más compleja y abierta (empírica, tanto cuantitativa como cualitativa, y reflexiva o ensayística) que la de otros ámbitos menos problemáticos, por el bien de la sociedad y de la propia educación.

Así, la educación se transforma, vía currícula prescriptivos, en un 'lecho procústeo' manipulable, de fanatismo variable, arbitrario y con base en la creencia, en un conocimiento científico seleccionado compatible y en intereses no pedagógicos, a los que deben ajustarse instituciones, profesionales y alumnos. Esta inducción adoctrinadora o este desastre educativo se suele simultanear con enseñanzas verdaderamente formativas. El resultado de la mezcla -que no llega a ser combinaciónes la 'educación normal', 'habitual' o lo que entenderemos por 'nuestra educación'.

Hay quien niega que esta calamidad se produzca, y sostiene que no existe. Lo hacen, por ejemplo, quienes ven los estiramientos y las hipertrofias como algo conveniente, porque favorecen o están sintonizados con los intereses egocéntricos de sistemas o ismos con los que simpatiza o a los que pertenece. También hay quien, cuando se amputa, no ve que se esté guillotinando nada, porque reconocerlo significaría autocrítica, crisis profunda y rectificación, y esto es algo a lo que el ego no está dispuesto en absoluto. No hay que olvidar que el ego es el caballo de Troya de la formación.

Un ejemplo de estiramiento es el adoctrinamiento, la parcialidad y el sesgo, a veces permanente o a veces cambiante, de todo tipo (ideológico, religioso, sexista, cultural, localista, nacionalista, internacionalista, científico, lingüístico, etc.), 
para cuyo desarrollo se condiciona la educación, que a su vez lo pretende y cultiva.

Un caso tipo dentro de este ejemplo tiene que ver con la elección del tipo de educación de los hijos en función de las creencias de los padres. Como la Pedagogía no contribuye con claridad a la diferenciación entre educación y adoctrinamiento, el panorama es confuso para muchos. Un indicador de este embrollo es que se entienda como algo normal y deseable que los padres o tutores puedan elegir la educación de sus hijos en función de sus creencias y convicciones derivadas. En primer lugar, si hay varias 'educaciones' no se tratará de educación, sino de adoctrinamientos; o sea, de opuestos a la educación. Las múltiples 'educaciones' están planificadas desde el ego colectivo, los ismos, etc. La educación es única y tiene como fin el despertar de la conciencia. Al despertar, una de las cosas que se distinguen claramente es el ser y la añadidura. En segundo lugar, las creencias no permiten decidir más que más creencias en el mismo sentido de la identificación. Eso no es elegir, sino proceder conforme a la "inercia cognoscitiva" (Herrán, 1997) generada por ellas y que precisan para su desarrollo sistémico. Ese procedimiento se desarrolla desde ego colectivo y personal, no desde conciencia. Cuando hay formación, las creencias pierden toda la importancia que se les concede arbitraria, interesadamente.

La anterior crítica es delicada, pero sería muy cómoda para los más críticos, porque automáticamente se excluirían del adoctrinamiento. El problema es más fino de lo que parece, en contextos de enseñanza: el adoctrinamiento de los más comprometidos con la educación puede ser, así mismo, un hecho. La diferencia con el de los ismos sociales es que el grueso de su acción institucionalizada consiste en eso. Los comprometidos debemos ser conscientes de que, como apuntaba Skinner, una metodología poderosa y eficaz de enseñar puede condicionar y evitar el mérito de aprender del alumno. Por ello, es preciso habilitar varias medidas de "respeto didáctico" (Herrán y González, 2002).

Así mismo, se incluirían como ejemplos toda clase de aceleraciones, de obsesiones, de clasismos, de fobias, etc. Comprendería la presencia de muchas enseñanzas a nuestro juicio inadecuadas, entre ellas la enseñanza multilingüe y las estafas de las religiones (Herrán, 2018a).

Un ejemplo de mutilación de la educación es lo que hemos considerado exclusión de temas radicales: la ignorancia, la inmadurez, el ego humano, el adoctrinamiento, el descondicionamiento y la desidentificación, la conciencia humana, el autoconocimiento, la finitud y muerte, la universalidad, la humanidad, la barbarie, la educación prenatal, el amor, etc. También se intenta cortar las alas de quien se cree que vuela más alto, más rápido, más bello... Son los egos interpretativos los que lo hacen o lo permiten.

De la violencia procústea de la educación deducimos algunas implicaciones para la formación:

- Los procesos de descoyuntamientoestiramiento o de cercenamiento-exclusión pueden entenderse como formas de violencia antipedagógicas. Todas se generan, bien desde sistemas egocéntricos, en función de decisiones externas intencionales -que a su vez dependen de la mirada externa y de intereses egocéntricos-, bien desde la ignorancia, para luego mezclarse con la educación y promover su resultado. Equivaldría a echar agua al vino, para venderlo como vino, o sea, a una estafa en toda regla, si bien es una práctica general.

- Se dirigen, preconsciente, sutil o descaradamente, a otros sistemas: 
naciones, sistemas educativos, centros docentes, profesores, alumnos, familias, educación, etc. Algún ejemplo de decisión intencional es un adoctrinamiento ideológico, y otro de ignorancia es la ausencia de un "tema radical" es la conciencia de la humanidad en la educación. Los primeros requieren de una intervención de los sistemas interesados; los segundos tienden a completarse con el tiempo y complejidad de conciencia. Pueden adoptar la forma de adoctrinamientos (nacionales, ideológicos, religiosos, culturales, sexistas, clasistas, etc.), obsesiones didácticas (polilingüismo, enseñanzas promovidas o financiadas por lobbies multinacionales -por ejemplo, la enseñanza del holocausto judío o la shoa-, nacionales, culturales, económicos, empresariales, militares, etc.), exclusiones curriculares, etc.

- Como son generales, pueden pasar desapercibidas. Otras, se admiten, pero se toleran, por razones de supervivencia o de interés práctico -por ejemplo, la enseñanza del inglés-. Otras, se desean, no viéndose inconveniente en su desarrollo -por ejemplo, el adoctrinamiento confesional en un estado teocéntrico-. Otras, se rechazan -por ejemplo, una educación que tenga en cuenta la muerte, porque se entienda que la escuela no debe ocuparse de ello-, etc.

- Lo contrario a los contenidos asimilables a la violencia procústea son las acciones conscientes basadas en el no hacer (wu wei) -en que repararon tanto Lao Tse (2006) como Rousseau (1987) (Herrán, 2012)-, o deducidas de una comprensión profunda de la educación y de un respeto didáctico centrado en la condición, y no en la calificación o cualificación humanas. Una acción formativa requiere de su interpretación y diagnóstico pedagógico.
- Si hay reconocimiento de este error violento de la educación, un corolario formativo puede ser: a una educación más plena se puede acceder mediante la exclusión de toda forma de violencia procústea. Si se entiende que lo hay pero que los cambios apuntados son imposibles hoy (utópicos), podrá significar que su realización es posible mañana. Se podría recurrir a una planificación a mayor plazo. En Herrán (1993) se proponía el concepto de 'super reforma de la educación', a varias generaciones vista y de ámbito universal, por tanto, promovida por organismos internacionales de educación. Requeriría revisar en profundidad el conceptofenómeno de la educación y articular un proceso de orientación para el filtrado entre lo que educa y lo que condiciona o deforma, por un lado, y otro proceso para completar la educación a través de la normalización e inclusión de lo que más tarde denominamos temas radicales. Quizá fuese necesario debatir sobre el constructo 'evolución de la educación'. Para un mejor transcurso de esta clase de reforma de la educación (Herrán, 2011d) será imprescindible que todos los sistemas sociales se sepan 'sistemas educativos' o con conciencia educativa, primero, para aplicarse en sí y, después, para coadyuvar a una evolución social apoyada en una nueva forma de paideia.

- Desde el enfoque radical e inclusivo, el sentido o vector de la posible evolución educativa es el mismo que el de la formación: del ego a la conciencia. Por tanto, podría interpretarse como un proceso que transcurriría del 'estadio procústeo' actual a otro más lúcido y centrado, apoyado en una mejor comprensión de la educación. Sus líneas de actuación iniciales podrían ser dos: a) Reducir progresivamente los estiramientos (excesos o amplificaciones 
con un interés más egocéntrico que pedagógico), y b) Iniciar la inclusión educativa de temas o retos radicales en la educación normal. Su normalización curricular, posiblemente, consistiría en una transformación de su actual estado radical (esencial y no demandado) a transversal (esencial y existencial, demandado y socialmente percibido).

- En este sentido, la única posibilidad de que nuestra educación pueda evolucionar es que la violencia procústea se deje de cometer. Para ello es preciso ir incluyendo paulatinamente los temas radicales, mientras se filtran y desechan los aditamentos o condicionantes. La ausencia de los primeros mantiene al ser humano en su propia exterioridad. La presencia de los segundos, le tienen narcotizado y dormido. Es preciso evitar que el viajero se quede dormido. Del mismo modo a como se respetan otros ámbitos sociales, es preciso que la educación deje de ser manipulada y deteriorada por el ego humano.

- En resumen, una forma concreta de iniciar la espiral evolutiva es facilitando el concurso de un par de fuerzas, mediante dos impulsos: el primero fue apuntado por Condorcet (1922, 1980): identificar y sacar de la educación todo lo que la condiciona o la tiñe, fundamentalmente proveniente de política y de religión. Por otro, ir avanzando en el proceso de toma de conciencia o comprensión de la necesidad formativa asociada a la inclusión de temas radicales en la educación. A medida que se avance en complejidad, ambas ramas convergerán, dando lugar entonces a una 'educación para un estado consciente'. Pese a ser insuficiente -por deber ser seguida de la acción consciente-, habrá descrito un paso evolutivo cuyo sentido podrá reconocerse.
- Para acompañar a este proceso será imprescindible un cambio radical en la Pedagogía y en las demás Ciencias de la Educación, con el fin de actuar como fuente de visión evaluativa y de respaldo científico. La Pedagogía tendría que pasar de la inhibición social al primer plano, por ejemplo, pronunciándose como ciencia con total claridad ante el fenómeno milenario del adoctrinamiento religioso (Herrán, 2019). Se recomienda contar con la asesoría de pedagogos expertos que compartan la existencia de esta violencia procústea, y dispongan de una formación radical e inclusiva o equivalente. Desde aquí, no sólo con ellos, pero no sin ellos.

Dos conclusiones, a modo de síntesis. La primera, descriptiva, surge como consecuencia de dar la vuelta a la metáfora de referencia: Procusto no fue un posadero, sino un psicópata asesino, ni 'nuestra educación' es 'educación' aún: para ser tal le queda un recorrido evolutivo que se puede pronosticar.

La segunda es alternativa: se trataría de que nuestro sistema concebido para la educación se pareciera cada vez menos a la posada de Procusto -destinada a comer, dormir y a soportar el peso y/o el corte de las alas- y más a la Residencia de Estudiantes, en la que tantos ilustres despertaron y crecieron. Entre ellos estuvo Lorca.

Como recuerda García Flores (2017), a los 24 años el poeta está en una encrucijada: había abandonado la carrera de Derecho, y "El maleficio de la mariposa", su primera obra de teatro, había fracasado. Sus padres le pedían que volviera a Granada. En una carta que Federico escribe a sus padres en 1922, les pide que le dejen seguir en la Residencia de Estudiantes, que tiene un "ambiente maravilloso" y que "no es ninguna fonda". Les dice, además que: "Yo he nacido artista, como el que nace guapo, como el que nace cojo. Dejadme las alas en su sitio, que yo 
os respondo que volaré bien (...) si me devolvéis a Granada me ahogo".

\section{POSIBLES ERRORES DE ENFOQUE $Y$ ENTENDIMIENTO}

\section{La educación y la formación están mal enfocadas: metáfora de la Luna}

La educación es como la Luna. Cuando la miramos, sólo vemos una parte. Lo habitual es ver y pensar en que lo que vemos es la Luna. Pero eso no es así: hay una cara lejana, hay una interioridad en el satélite, hay una relación dinámica con otros cuerpos, etc.

De lo que no vemos apenas nos ocupamos, o bien se niega su existencia. Se ve más y mejor, a medida que se incrementan la complejidad y la conciencia y, con ellas, la zona del próximo desarrollo (Vygotski, 1978). Hace 60 años, la educación medioambiental, la educación vial o la educación para la salud y sexual estaban ocultos, no se veían. Eran, en sentido estricto, temas radicales. Su conciencia y normalización los transformó en transversales, al menos intuidos con claridad y socialmente demandados.

Como ocurre en los objetos de estudio de otras ciencias, en educación sólo estamos viendo y considerando la periferia del fenómeno. Casi todo está bien, superficial, aparentemente, y casi todo se desarrolla con un grave déficit radical. Como consecuencia de ello, no estamos educando, no estamos formando.

La educación es más -y mejor- que lo que se intitula, y la Pedagogía tendría que ser formativamente más consciente, ambiciosa, profunda e inclusiva de ámbitos muy relevantes, ignorados o excluidos, de facto, de la ciencia normal. En ellos la academia no suele reparar. Sin embargo, sin su normalización, la educación y la formación, sencillamente, no son posibles.

Una Pedagogía basada en la conciencia, antes de educar para la vida, la observa. Vivimos mal, en el exterior de nosotros mismos, y la forma de entender tan externamente la educación es sólo un efecto isomórfico de la vida desequilibrada de sus individuos: socialmente es parcial, insuficiente y sesgada, etc. porque dentro análogamente lo es.

Para completar la educación no se trata de generar más saber, sino más conciencia. El saber no siempre trae conciencia, y la conciencia no siempre necesita de mucho saber o de tanto aprendizaje significativo y relevante de conocimientos. A veces, el saber o los conocimientos disponibles son un obstáculo para la conciencia.

Por eso el reto básico tiene que ver con la conciencia, de la que apenas se habla, por ser uno de los temas o retos radicales, de los que ni la Pedagogía ni la educación se ocupan. Otros retos radicales estarían relacionados con los huecos de la educación ordinaria, otros, con el diagnóstico pedagógico del ser humano, y otros, con alternativas formativas con base en la conciencia. El reto global es la compleción de la Pedagogía y de la educación.

\section{No sabemos qué son la educación y la formación}

En el campo de la educación y la enseñanza, no se puede estar a la última sin estar a la primera. Por eso, por ejemplo, enseñar sin compromiso con la tarea no es posible. No es posible en absoluto saber enseñar sin saber qué enseñar. Innovar sin conocimiento básico y eficaz, tampoco puede ser. Sin embargo, al parecer, se educa, sin entender bien lo que es la educación. Este fenómeno ocurre por tres razones básicas que se retroalimentan: porque su observación está mal enfocada, porque no se sabe que su significado se ignora, y porque no hay mucho interés en reconocerlo y entenderlo.

Si algo define a la educación ordinaria es su error de enfoque interpretativo y, como consecuencia, su insuficiencia esencial. El 
entendimiento de nuestra educación responde a cuatro déficits provenientes de sendas carencias interrelacionadas: su conceptualización parcial -de una parte por el todo-, su falta de profundidad, su miopía y su descompensación dinámica. La causa común es la ausencia de centro o de eje plectonémico, según se observe desde lo alto o desde un lado, como una espiral evolutiva. El efecto resultante es una trayectoria social y educativa desorientada y precipitada, corticalmente pensada.

Por eso el centro de gravedad se coloca en la acción y, desde ella, se busca atajar. En la educación el camino más corto no es la línea recta, sino la curvatura. En línea recta, avanzar es retroceder. $Y$ no hay atajos. Normalmente, la acción educativa se apoya en el alumno y se identifica con el quehacer de los profesores en el marco del sistema educativo. Ni siquiera ampliando la atención a los padres sería suficiente, no se podría llegar al final del camino formativo. De hecho, en los mejores casos, no se llega.

No se trata tampoco de que la educación esté más presente en el discurso habitual de los medios, la política, la familia, etc. Podría pensarse que sería un logro que estuviera más presente y que, por lo menos, se hable de ella. Pero no lo es, porque hablar sin conciencia no sirve para nada. O mejor, podría servir para creer que hablar de educación vale para algo, o para mostrar a los demás que se hace algo, para aparentar.

Seamos honestos: normalmente, no se desea conocer. Lo que se desea a toda costa es creer que ya se sabe $y$, en todo caso, hablar para reafirmar las propias tesis, la propia creencia, el propio ego. No tenemos conciencia clara de nuestra ignorancia, ni nos han educado para eso. Esto, junto al egocentrismo y sus interacciones, constituye el origen de todos los males educativos y, a la vez, la posibilidad de acceder a un escenario que podría calificarse como sociedad de la educación o de la formación.

Es como prepararse para una excursión: habrá que cuidar el equipo, revisar la mochila $y$ saber a dónde vamos. Por lo que respecta a la educación, es clave comprender de qué se trata, ser consciente del objeto al que nos referimos, incluyendo en ello la posibilidad de que una parte de ella no sea ningún objeto.

El problema es que, normalmente, la educación sólo se identifica con la parte emergida del iceberg, o sea, con su exterioridad. Es como si identificásemos a una persona con su maquillaje o con su personalidad: con esta expectativa, nunca se llegaría al ser. Por tanto, quizá entre lo primero esté deducir qué no es la educación. Lo habitual es ignorar lo que la educación es y no reconocerlo, y este acto de conciencia es esencial para comenzar bien, incrementar la posibilidad de comprenderla y llegar a la meta alguna vez.

Se educa en función de lo que se ve, y se ve muy poco. Esto es de aplicación a investigadores, profesores, padres y a todo agente ocupado en la educación. Lo que se ve depende de la conciencia que se tiene. La conciencia es el resultado fundamental de la educación. Como lo que se favorece no es la educación completa, la conciencia es escasa, y su pronóstico normal es así mismo limitado. En general, tanto desde el punto de vista de los resultados individuales como sociales podría asegurarse que no se está educando. Ocurre como a un hospital del que los ex pacientes salieran medio curados o con una salud a medias. No se es consciente de que lo que se considera 'educación' no se orienta expresamente a la promoción de la conciencia o a la vida en un estado más consciente (Herrán, 1998a), porque este constructo esencial no ocupa apenas lugar entre sus fundamentos pedagógicos básicos. 
Por eso, con frecuencia se llama 'educación' a lo que mientras forma, deforma: todo a la vez. El engrudo resultante no sirve para que la circunferencia de cada ser humano y de la humanidad salte del plano al espacio, o muten de curvatura plana a espiral. Sin apercibirse de ello, por un lado nutre y, por otro, agrega petróleo o cemento a las alas de cada ser humano. Y así no muta nada, ni es posible volar, ni personal, ni socialmente.

Esta educación converge en desarrollo exterior, a costa de un abandono o un olvido del interior. Decimos 'olvido', porque en algún momento de la historia de la innovación educativa se fue consciente de ello. El ser humano resultante es la criatura de Frankenstein, en quien se tiende a desarrollar todo a la vez vía yuxtaposición: inconsciencia, competencias, prejuicios, creencias, aprendizajes significativos y relevantes, condicionamientos varios, tribalidad, ego personal y colectivo, conocimientos, estulticia, fanatismo sistémico, etc. Del interior se desconoce todo, entre otras cosas porque no hay nada que conocer. Esto también se ignora en absoluto.

\section{Algunas deducciones radicales:}

- No se trata de educar para la vida, ni de formar en competencias. Si la vida humana es social y personalmente un desastre, ¿qué sentido tiene 'educar para la vida'? Si 'educar para la vida' depende de lo que por 'vida' se entiende, puede hasta hacerse equivaler a 'aprender durante toda la vida' (Medel, 2003; Chisholm, Larson \& Mossoux, 2004; Colardyn \& Bjørnåvold, 2005) y a 'educar con base en competencias'. Pero esto es una contradictio in terminis: no es posible: habría que deteriorar el significado de 'educar' para su encaje. Lo único que objetivamente tiene sentido, a la vista de la vida humana y de su educación, es educar para cambiar la vida y hacerlo radicalmente.
- Los diferentes impulsos renovadores de Giner de los Ríos o Cossío, de Dewey o Kilpatrick, o de Pestalozzi-BasedowMontessori-Freinet -por citar algunosfueron necesarios. Pero es preciso ir más allá y más al interior, y concluir que hoy estamos a las puertas de "otra nueva educación” (Herrán, 1996).

- Todos los organismos crecen y se reparan. Por tanto, no se trata de la funcionalidad significativa o relevante, ni de seguir haciendo camino. Puede que lo más urgente sea pararse, seguir preguntándonos "qué estamos haciendo" y "qué estamos construyendo" (Herrán, 1993), hacia dónde vamos y, sobre todo, quién es el ser esencial que se cuestiona esto. Lo necesario y suficiente, aunque los organismos internacionales y los sistemas educativos no lo expresen, es educar para 'despertar'.

- La educación está más cerca de la complementariedad y de las síntesis que de las dualidades, porque toda dualidad es falsa o superable, y porque hay más de una docena de modos de superarlas vía conciencia dialéctica (Herrán, 2003). Si se identifica con una dualidad, no se estará educando ni podrá hacerlo con los demás.

- El ser despierto es el ser en estado consciente. Este ser, se educará para la vida espontánea, automáticamente, y lo hará desde sí y desde fuera, simultáneamente. Por tanto, se educará con base en la conciencia y con base en competencias a la vez.

\section{Los 'fines de la educación' son incompletos o inválidos para una educación plena}

La educación y la formación no incluyen fines radicales. Los fines de la educación consensuados no son los fines de la educación. Sólo son los fines de lo que se llama educación. 
A lo que aluden no es la educación plena, como una persona no es su personalidad o su pensamiento. Pudieran considerarse necesarios, pero insuficientes.

Se proponen los siguientes, que responden al epígrafe común "Educar para...". A cada uno le correspondería una Pedagogía aplicada. No se ha huido del solapamiento. Todos están interrelacionados.

a) Fines de la educación asimilables a insuficiencias, errores, sesgos y huecos (ausencias) de lo que en la educación normal o en 'nuestra educación' se hace:

\section{Educar para:}

- ser conscientes del propio y general estado de condicionamiento egógeno.

- ser conscientes de la insuficiencia general de la educación actual

- diferenciar entre educación superficial y situada y educación radical, común a todos los contextos.

- ser conscientes de la insuficiencia de nuestra educación

- ser conscientes de la dimensión radical de la educación y de la formación, sin la cual la educación plena no es posible

- discriminar entre adoctrinamiento y educación, según provenga y se destine al ego o a la formación, sin calificativos.

- identificar los lastres de la conciencia. Por ejemplo: condicionamientos, identificaciones, prejuicios y otros conocimientos sesgados, apegos $y$ dependencias de ubres e ismos, cavernas personales, institucionales $y$ sociales, etc.

- ser conscientes de que todos los sistemas educativos actuales adoctrinan mientras educan.
- ser conscientes de que los currícula están condicionados por sus sistemas educativos $y$ de que son insuficientes para educar plenamente.

- comprender la parcialidad asociada a una educación basada en el aprender, o sea, en la adquisición significativa y relevante de conocimientos y saberes, si no incluye la pérdida, la eliminación, el autoconocimiento $y$ otros temas radicales (huecos, de diagnóstico y de alternativas) en su desarrollo normal.

- comprender la parcialidad asociada a una educación basada en constructos recurrentes e insuficientes como aprendizajes, saberes, competencias, personalidad, diversidad, niño, sistema educativo, etc.

- comprender la parcialidad asociada a la educación desde los 0 años de edad y la potencialidad de la educación prenatal.

- discriminar entre creatividad objetal y creatividad consciente.

- ser conscientes de que el centro de la educación no es el alumno, porque todo sistema humano es centro de la educación.

- ser conscientes de que no se está formando plenamente al profesorado.

- ser conscientes de la insuficiencia de la noción actual de 'cambio educativo'.

- ser conscientes de la insuficiencia de la orientación científica normal, etc.

b) Fines de la educación asimilables a propuestas de diagnóstico radical, que hoy no se hacen, no se incluyen o no están normalizadas en la educación normal:

Educar para:

- reconocerelpredominante egocentrismo del ser humano, incluido el nuestro y el 
de nuestros sistemas de identificación.

- entender el condicionamiento del ego en la razón: dualidad, parcialidad, sesgo, etc.

- tomar conciencia de la desorientación esencial del ser humano.

- diferenciar entre el plano de lo existencial y lo esencial.

- diferenciar entre vivir en estado de inconsciencia $y$ vivir en un estado consciente.

- discriminar entre conciencia ordinaria y conciencia extraordinaria.

- tomar conciencia de las grandes "certezas formativas", de alcance propio y general (ver parágrafo correspondiente), etc.

c) Fines de la educación asimilables a alternativas radicales que aún no existen plenamente o que no están incluidas $y$ normalizadas en 'nuestra educación':

Educar para:

- la apertura mental.

- la interiorización.

- el equilibrio entre lo existencial y lo esencial.

- ser conscientes de que la educación de los demás comienza en la propia empecemos por educarnos-.

- ser conscientes de que cada sistema humano (personal o social) es un centro (causa, sujeto y objeto) de la educación.

- tomar conciencia de ser, cada uno, una persona normal y corriente algo excepcional en la sociedad del egocentrismo-.

- diferenciar entre lo que viene del ego y lo promueve, y lo que surge y favorece la conciencia.
- entender que la educación es un proceso evolutivo (personal, social, filogenético, etc.) que transcurre del ego a la conciencia.

- aprender o adquirir conocimientos, pero también para perder apegos, dependencias, condicionamientos, identificaciones, parcialidad, dualidad, sesgos... egógenos.

- reidentificarse (con lo que se estime conveniente) más allá del ego.

- el autoconocimiento -o descubrimiento de la identidad esencial o de la naturaleza original de cada ser-, más allá de la personalidad y de la mente.

- $\quad$ para vaciarse y ser el vacío.

- el despertar a un estado consciente (en otros contextos se llama budeidad).

- vivir desde el ser (autenticidad), no desde el ego.

- una creatividad total (o equivalente: externa e interna a la vez).

- saber qué es y cómo meditar.

- la unidad del ser humano con la naturaleza.

- la unidad del ser humano.

- la síntesis, más allá de la dualidad.

- la coherencia consciente (no rígida).

- la toma de conciencia de la posible evolución humana, de la que la educación es el factor clave desde subprocesos formativos de aprendizaje, construcción, eliminación, destrucción, complejidad y conciencia.

- la duda.

- la desobediencia y la autonomía -en determinados contextos de falta real de libertades, injusticia y atentado contra la 
dignidad humana-.

- la humildad de la razón.

- la madurez personal, institucional y social.

- la universalidad y la unidad del ser humano,

- la posible evolución educativa humana, más allá del desarrollo y el progreso.

- ser conscientes de que formamos parte de una humanidad en evolución, que trasciende a los ismos y a los sistemas sociales egocéntricos.

- un lenguaje universal, democrático, equitativo, más allá de las influencias e intereses parciales de sistemas egocéntricos.

- la relevancia y posibilidades personales y sociales de la educación prenatal.

- la atención y la correspondiente educación para la unicidad, más allá de la atención y educación basadas en la diversidad, en la identidad, en la semejanza...

- la formación de educadores y profesores con base en enseñanzas de los grandes maestros del bien común, más allá de las religiones, las filosofías, las tradiciones $y$ otros ismos.

- para comprender el amor y vivir amando, etc.

\section{MEDIANTE EL APRENDIZAJE Y EL CONOCIMIENTO NO SE PUEDEN} ALCANZAR LOS FINES CRUCIALES DE LA EDUCACIÓN

Con aprendizaje y conocimiento no se llega al final del camino de la educación, que es el despertar de la conciencia, el autoconocimiento, el vacío y la unidad del ser humano. Sin embargo, las mochilas de los investigadores, profesores, alumnos, educadores, sistemas educativos... no contienen otra cosa. Se da la paradoja de que se habla de llegar al final y del pleno desarrollo de la personalidad, etc. No puede ser. La cuestión no consiste en capacidades ni en personalidades. Ninguno de ellos está al final. Otra cosa es que a esos puntos se llame 'final del camino'. Si se hace sin conciencia, será un error $\mathrm{y}$, con conciencia, una verdad a medias. Ni el aprendizaje, ni el conocimiento, ni las capacidades, ni la personalidad, ni las emociones tienen que ver con la plena educación. A lo sumo, con la plenitud de una fase inicial de la educación.

Cuando no se llega a la meta, puede ser por varias causas: por despiste, por mal funcionamiento del vehículo, si lo hay, por impericia del conductor, porque quizá la meta no estaba donde se creía, porque quizá nunca existiera ni meta ni carrera, quizá por varias de estas u otras razones a la vez. En educación y en formación, incluida la de profesores y de educadores, los más conscientes de la acción educativa deberían ser los investigadores de la educación y los educadores, desde la educación prenatal hasta la universitaria.

Desde el enfoque radical e inclusivo, nuestra conclusión es que el proceso de la educación se comprende parcialmente. Si en ella se pudiesen definir cinco fases, por mor del condicionamiento socrático de siglos antes comentado, sólo nos estaríamos ocupando de la primera. Al ser humano le ocurre como a veces a los niños pequeños en un viaje: que se duermen pronto, de modo que, como mecanismo de defensa, sólo ven la primera parte del trayecto y el final, cuando les despiertan. Distinguiremos las siguientes fases de la educación:

a) Fase de adquisición de saberes y condicionamientos: En esta fase, la educación se asocia a presencias o adquisiciones deseables, planificadas o no, de saberes, aprendizajes, conocimientos, 
competencias, experiencias, valores, reflexiones, pensamientos, emociones, etc.), con las que se identifica la educación normal o 'nuestra educación'. Se centra en constructos como enseñanza inclusiva, democrática, metodológicamente variada y motivadora, atención, motivación, voluntad, aprendizaje significativo y relevante, competencias, entendimiento, memoria comprensiva, responsabilidad, ética y valores, personalidad, creatividad, emprendimiento, autorregulación, etc.

Su peor versión es el adoctrinamiento (nacional, religioso, cultural, ideológico, clasista, etnocéntrico, sexista, 'Igtbi...fóbico', racista, etc.), el fanatismo en grado variable, la parcialidad, el sesgo, la inmadurez, la superficialidad, la desorientación, etc., que pueden coexistir descaradamente junto a brotes de educación de calidad. Su mejor versión es la razón equilibrada, curiosa, crítica, creativa, cuestionadora, democrática, que busca la mejora y la justicia social.

Este es el nivel de trabajo de nuestra educación. Los sistemas educativos y los organismos internacionales no conocen otra educación. Tampoco parecen deducir que ésta es necesaria, pero insuficiente o que no equivale a toda ella, sino a una fase. En su mejor versión, es completamente insuficiente.

Lo habitual es proceder desde el condicionamiento de los sistemas educativos y esgrimiendo con total normalidad lo que hemos considerado "currícula descarados", esto es, nada ocultos, desde y para el adoctrinamiento, abiertamente deformativos y procediendo como hacen casi todos los demás. (Si todos lo hacen, ¿cómo podrían estar equivocados? Nuestra conclusión es que sí, que todos los que lo hacen lo están, y que son todos.) No es difícil proceder con esta inercia, porque todos los sistemas educativos están viciados de origen, al ser sistemas nacionalistas o, últimamente, internacionalistas. Esto es, desde los sistemas educativos se suele actuar desde y para ismos parciales (nacionales, ideológicos, religiosos, culturales, étnicos, etc.), pensando en su diversidad como valor y en que, por ello, los demás no son como ellos. Actúan desde la dualidad, la parcialidad, la identificación, la incoherencia pedagógica, muy lejos de la educación misma. Por definición, están alejados de la humildad, la duda, la autocrítica, la capacidad de rectificación, de renuncia, la conciencia distanciada y empática a la vez, la síntesis, la humanidad, la universalidad, etc.

También la instrucción y el saber disciplinar pueden condicionar y sesgar desde enfoques, preferencias, creencias, escuelas, omisiones, mentiras, etc. También una instrucción aparentemente insesgada puede caer en el condicionamiento si, por ejemplo, enseña sin la duda (Herrán, 1998b), si oculta y muestra una parte, si llama 'todo' a lo que enseña o a lo aceptado para manipular, si totaliza lo parcial, si, enseñándolo todo, asocia actitudes diferentes a una y otra parte, si distorsiona algo de lo que enseña, si exacerba, si amputa, etc.

b) Fase de toma de conciencia del condicionamiento: No es común que la educación continúe como esta o las siguientes fases. En esta fase, la educación se traduce en capacidad de visión y de discriminación entre varios pares polares: lo existencial y lo esencial, la programación mental personal y colectiva y la persona, la personalidad y el ser, la identificación con los ismos y la razón consciente y autónoma, el condicionamiento o añadidura y la conciencia, el ego y el amor, etc. Se intuyen 
temas radicales, no demandados, pero claves para la formación.

Nuestra educación se ocupa poco o nada de esta fase. Cuando lo hace, suele proceder de un modo escorado o sesgado, entre otras cosas, porque esta toma de conciencia no es una pretensión educativa normal, ni está orientada por ningún fin de la educación asimilable. En este sentido, los sistemas educativos son como mercados: todos venden algo en nombre de sí mismos. Lo único importante es que se compre su 'proto producto', que es la identificación tribal, el condicionamiento asociado y su adoctrinamiento normal, eventualmente mezclado con excelente educación.

c) Fase de descondicionamiento o desidentificación: En esta fase la educación se centra en la liberación, la eliminación, el desecho, la defecación, la relegación, la renuncia, la disolución, el desaprendizaje, la muerte, etc. de condicionamientos, identificaciones, dependencias, apegos, ataduras, parcialidades, dualidades, creencias, aprendizajes, predisposiciones, prejuicios, fanatismos, ignorancias, estulticias, iras, codicias, lastres, sesgos, tóxicos, tintes, etc. para la evolución educativa de sí y del entorno. Es acción consciente, más que olvido, aunque también pueda contribuir en los periodos de sueño fisiológico. El análisis consciente puede ser útil para esta fase, pero lo más útil para la pérdida es la meditación. Meditar es observar. En este contexto, se trata sólo de observar los condicionamientos y demás añadiduras. A medida que la observación se interioriza, tienden a desprenderse del ser, como la vieja piel de un reptil, debido a su crecimiento, o como las células muertas de nuestra propia epidermis. La pérdida de lo viejo, de lo trascendido, de lo superado asocia un placer especial. Se disfruta perdiendo condicionamientos, como cuando nos limpiamos o se orina. Se sueltan y se dejan para no volver a retomarse.

En el contexto de la "sociedad del egocentrismo" (Herrán, 1993, 2008, 2014, 2015, 2016), construida sobre la acumulación y la adquisición para el tener, nuestra educación no ha entendido que educarse también es perder. Los árboles pierden células, hojas y ramas; no es un drama, sino un avance. Todos los seres vivos lo hacen. Sin pérdida celular, no hay vida. Identificar la educación o la vida personal y profesional sólo con adquisiciones es absurdo, insuficiente o un error, proveniente de la asimilación de la educación a una sociedad acumulativa, también de aprendizajes y conocimientos. De hecho, todos los conocimientos son adquisiciones, todos los aprendizajes son adquisiciones (vengan por recepción o por descubrimiento), las competencias están formuladas en términos de presencias con las que se gana.

¿Cómo es posible que la academia, los sistemas educativos, los organismos internacionales de educación, los fines de la educación, etc. no estén formulados, también, en términos de pérdidas con las que se gana? ¿Cómo puede ser que la ganancia en tres indicadores instructivos se considere un éxito de la educación para los informes Pisa, y que el incremento paralelo de xenofobia parezca invisible? Nos sigue pareciendo necesario el desarrollo de lo que en otro lugar llamamos "didácticas negativas" (Herrán y González, 2002), centradas en presencias con cuya pérdida se gane. Por ejemplo, didáctica del prejuicio, del fanatismo, del adoctrinamiento, de la xenofobia, del sexismo, de la estupidez, etc. 
d) Fase de autoconocimiento: En esta fase, la educación se traduce en la experiencia de sí, en la conciencia experimental del ser esencial. La metodología es la meditación, en sus fases avanzadas o fértiles.

Nuestra educación se ha aproximado al autoconocimiento de varias maneras equivocadas (Herrán, 2004a; Álvarez y Herrán, 2009):

a. Desde un desconocimiento cabal de lo que es la educación plena y su recorrido, que aquí brevemente estamos describiendo.

b. Creyendo que el autoconocimiento es otro saber y siguiendo la vía de Sócrates y la Filosofía, en particular de Kant (1989), aunque él los diferenció.

c. Siguiendo las vías de las religiones institucionalizadas, cuyo desarrollo precisa el alejamiento del individuo de su autoconocimiento y la fe ciega en la ficción, tanto sobre Dios como sobre la (post) muerte.

d. Siguiendo la vía de la ciencia -en este caso, de la Pedagogía, la Psicología o la Psiquiatría-, que sólo se ocupa de lo exterior de lo interior y confunde la pregunta '¿Quién soy yo esencialmente?' con '¿Cómo soy yo existencialmente?' o ‘Cómo es mi personalidad?', que no tienen nada que ver, con lo que se han equivocado y han confundido por completo a la educación.

e. Excluyendo de las metodologías didácticas o para la formación la meditación, y desarrollando en su lugar sucedáneos pensados para el hombre y la mujer occidentales, como el mindfulness (Herradas, 2017; Herrán, 2017d).

Para la experiencia de autoconocimiento no hay que centrarse en la adquisición o en la pérdida. La mente, el saber, el aprendizaje, la reflexión, la pregunta, etc. no sirven para nada. El descondicionamiento, la desidentificación, la liberación, etc. no son útiles en este momento, porque son añadidura y pasado, y ninguno de los dos es. Para la experiencia del autoconocimiento no hace falta desplegar ninguna vela, porque no se trata de aprovechar ningún viento. Tampoco hay que arriarlas. Es indiferente. $\mathrm{Ni}$ siquiera es un tema de sentido, de adónde ir. Sólo es abrir los ojos y que las aguas se calmen. Cuando el fondo propio se calma, la identidad original se aclara. Se trata de vaciarse, de silenciarse, para ser la nada, el no saber, el no ser. Se trata de meditar (sin contenidos, sin objetivos, sin mente ni no mente) para que, al terminar, la meditación se siga practicando. Una respuesta consciente al autoconocimiento, una vez deducido lo que esencialmente uno no es, es 'no sé'. En el autoconocimiento, "el que sabe no habla, y el que habla, no sabe" (Lao Tse, 2006).

e) Fase de recondicionamiento o de síntesis: Se traduce en lucidez, superación de dualidades, razón dialéctica, conciencia de síntesis, de totalización (no dualidad, no parcialidad), de interiorización de los temas o retos radicales, etc. Esta fase puede darse sin o con autoconocimiento. Cuando se está en ella, puede parecer que se está en otra anterior, incluido el autoconocimiento, o puede que no.

a. Si se da sin autoconocimiento, es una fase que continúa a la ante-anterior. En este caso, no es la fase más avanzada o elevada. La conciencia será parcial: sólo se referirá al conocimiento, a los saberes, quizá con potencia reflexiva, con complejidad, con tanto brillo como falta de plenitud. Las experiencias serán intelectuales, exteriores o falsamente interiores. Podría hablarse 
de conciencia aplicada. La conciencia podría ser pseudo conciencia, un producto del ego.

b. Si se da tras la experiencia de autoconocimiento, será una expresión de un 'estado consciente', y no tanto de 'conciencia'. No son lo mismo. El estado consciente recuerda algo al estado original. Un aforismo zen lo explica:

Al principio, los ríos son ríos y las montañas son montañas. Cuando se avanza en el camino, los ríos dejan de ser ríos y las montañas dejan de ser montañas. Cuando se llega a la iluminación, los ríos vuelven a ser ríos y las montañas vuelven a ser montañas (Deshimaru, 1981).

Aunque desde fuera se parezcan, los primeros y los últimos ríos y montañas son radicalmente distintos, no tienen nada que ver entre sí. En esta fase, la meditación se sigue practicando como observación de la realidad.

Una síntesis y aplicación doble -de orientación personal y organizativa-, podría ser el que sigue: para la formación plena, no es suficiente con el aprendizaje significativo y relevante, ni con la eficacia en el hacer. Ni siquiera con la posibilidad de 'aprender a aprender' o aprender de sí. Hay personas muy eficaces y muy estúpidas a la vez. También las hay que han desarrollado la habilidad de aprender de sí mismas, de su acción y de los demás, pero adolecen de madurez, pudiendo o no ser eficaces. Esto puede ocurrir porque la eficacia, la competencia en aprender por sí y la madurez son dimensiones distintas e interrelacionadas, suficientemente independientes.

Este hecho puede constatarse en el plano de las organizaciones educativas. En su caso, el problema es precisamente ese calificativo: 'educativas'. Si nos pudiéramos referir a ellas como 'pseudo educativas o educativas', no habría ningún problema. Pero si se consideran todas educativas a priori, no se deberían detener en la eficacia, ni en la posibilidad de aprender de sí mismas. Sería imprescindible que avanzasen hacia la madurez organizacional e institucional (Herrán, 2011a, 2011b). En el trabajo en que se presenta el enfoque radical e inclusivo (Herrán, 2014) se ofrece un sistema de indicadores para describir, anhelar y evaluar órganos e instituciones educativas maduras, más allá de la eficacia y de la posibilidad de aprender de sí mismas.

\section{LOS PRINCIPALES FACTORES DE LA EDUCACIÓN Y DE LA FORMACIÓN NO SON TODOS LOS QUE SON}

Actualicemos una relectura de lo anterior, desde la concepción habitual de una educación supuestamente completa, articulada sobre la reflexión docente y la práctica (Herrán, 2011a), y orientada al aprendizaje o la adquisición de conocimientos. Quedaría representada así (Díaz Allué, 1996, comunicación personal):

'Educación = Instrucción + Orientación =
Formación'.

Nuestra revisión teórica y aplicada desde el enfoque radical e inclusivo de la formación añade un sumando, sin el cual la educación (plena) no puede tener lugar:

'Educación = Instrucción (con base cientifico-
tecnológica-profesional) + Orientación
(educación en valores y en virtudes) +
Enseñanza de retos radicales = Formación'.

Como la 'educación' o la 'formación' de la primera identidad no pueden equivaler a la 'educación' o a la 'formación' de la segunda, una de las dos no es correcta. Deducimos que en el primer caso habría que distinguirla calificándola como 'parcial', 'periférica' o 'necesaria pero insuficiente', o en el segundo habría de adjetivarse como 'plena', 'total', 'íntegra' o 'integral'. Desde nuestra perspectiva, 'educación 
plena' o 'formación integral' son redundancias, por lo que los modos más adecuados de proponer sendos esquemas serían:

- Para la educación y formación actuales:

'Educación parcial = Instrucción + Orientación =

Formación somera'.

- Desde un enfoque radical e inclusivo de la educación y de la formación:

'Educación = Instrucción + Orientación +

Enseñanza de temas o retos radicales $=$ Formación'.

Más allá de los matices relevantes relativos a la completez de una y de otra, las identidades de dos sumandos se asimilarían a la primera de las fases de la educación, y las de tres sumandos, a las fases segunda a quinta. En efecto, al incluir la 'Enseñanza de temas o retos radicales', se añaden la pérdida y el autoconocimiento como parte de ellos.

\section{La educación comienza en uno mismo. La teoría de la mora}

Si la educación que se quiere proponer o realizar no parte antes de una 'educación o formación en sí', se estará desarrollando un comportamiento incoherente. Podrá ser suficiente, pero será incoherente; podrá ser brillante, pero será incoherente.

Confucio (1969) exhortaba: "Ocupa siempre tu mente con la educación”. Su enseñanza nos remite a ocuparnos de la formación desde nosotros. El trabajo formativo personal es duro y difícil. No es el camino más corto. Es el único que hay. Los demás son atajos falsos, sólo sirven para creer que se va a llegar a un lugar equivocado, para perderse, llegar mal, para perjudicar a otros, si la tarea es educativa o pedagógica.

Cuando se trata de educadores naturales (padres o tutores legales) o profesionales, la autoformación es un imperativo. Pero en la sociedad del pseudoconocimiento, es un hecho a medias: en general, se forman aceptablemente maestros de infantil o de primaria, escasamente los de secundaria, y apenas nada, los de universitaria y los padres. Formación significa autoformación, transformación y evolución profesional y personal del ego a la conciencia.

Decía Confucio (1969) que la persona cultivada o educada era aquella que primero hacía las cosas y después hablaba de ellas. Cuando se trata de educadores de facto, lo primero debería ser tomar conciencia de serlo. Ahora bien, en la medida en que todos los sistemas sociales y personales pueden educar al enseñarse (mostrarse) y enseñar, se colige que todo sistema consciente primero se ocupa de sí mismo y se forma, luego hace las cosas y después habla de ellas. Esta situación idónea tiene poco que ver con la realidad, hoy.

Con el fin de verla mejor, salgamos de su indagación directa y percibámosla desde un par de razones que Montessori (2013) hace sobre el adulto y el niño: "El adulto se ha vuelto egocéntrico en relación con el niño; no egoísta, sino egocéntrico. Por lo tanto, considera todo desde el punto de vista de su relación con él mismo, y por lo tanto no comprende al niño". Si sustituimos 'adulto' por 'sociedad' y 'niño' por 'educación', se podrá leer: 'La sociedad se ha vuelto egocéntrica en relación con la educación; no egoísta, sino egocéntrica. Por lo tanto, considera todo desde el punto de vista de su relación con ella misma, y por lo tanto no comprende a la educación'.

Las dos frases definen una acción común. Esto es, intervenir sobre el niño o la educación a imagen y semejanza del interventor -el adulto o la sociedad, respectivamente-, esto es, de fuera a dentro, aunque se disfrace del sentido contrario.

Como alternativa, Montessori (2013) propone lo siguiente: 
El adulto debe reconocer que debe ocupar un segundo lugar; esforzarse todo lo que pueda para comprender al niño, y apoyarlo y ayudarlo en el desarrollo de su vida. Este debe ser el objetivo de la maestra y la madre. Para ayudar a desarrollar la personalidad infantil, ya que el niño es el más débil; el adulto con su personalidad más fuerte, debe refrenarse, y tomando ejemplo del niño, sentirse orgulloso si este puede comprenderlo y seguirlo.

Tanto si consideramos el texto de la autora referido al niño- como si seguimos con el juego semántico y sustituimos adulto por sociedad y niño por educación, respectivamente, no participamos del todo de su propuesta. ¿Por qué? Porque su exhortación es comportamental, y porque puede ser una consecuencia del error asociado a pensar que el alumno es 'el centro de la educación'. Es un craso error en que ya hemos reparado. Tanto cada adulto como todos los sistemas sociales, en tanto que educadores, deben saberse centros de la educación y, en consecuencia, ocuparse, en primer término, de su propia formación. Es preciso pasar de una geometría circular y plana -en torno a un centro que es el niño- a otra espacial y multicéntrica. Es lo que llamamos "teoría de la mora" (Herrán, 2016c, 2017a, 2017c). Desde ésta, cada sistema (personal o social) puede tener conciencia de ser un centro de la educación y, en consecuencia, comenzar por sí la acción educativa.

Cualquier enfoque centrado en el niño, en el alumno, en el hijo o en una acción educativa que se refiera a objetos externos rodea literalmente a cada ser, hace un baipás con uno mismo y coloca el centro de gravedad en la periferia. De este modo, la autoformación se aleja del imperativo formativo endógeno. Esta opción epistémica, que es la más cómoda, es absolutamente engañosa, porque no asegura la coherencia.
Cuatro corolarios, del más externo al interno:

- El primero se refiere al plano político: si la educación se comprendiese, automáticamente se anhelaría y favorecería un pacto de estado sobre educación (Valle y Toribio, 2008), de modo que ésta se consideraría res extra comercium. Como estamos a nivel del suelo en lo que a sensibilidad y cultura general pedagógica se refiere -precisamente por entender que la educación es algo de los alumnos, del sistema educativo o de las familias y que, por tanto, poco tiene que ver con cada ser-, basta con que un partido político lo proponga para que sea rechazado por otros no afines, por esta sencilla razón radicada en el ego: ellos no la plantearon, por tanto, no podrán esgrimir su logro como conquista crucial o de su ismo; se evita así que el partido proponente esgrima su iniciativa para prevalecer sobre sus sistemas rivales. Dicho de otro modo: se renuncia al bien común para que el de enfrente pierda. El substrato de sendas actitudes es el razonamiento egocéntrico anti cooperativo, asociado a parcialidad, inmadurez, falta de comprensión y de conciencia. Desde estas coordenadas, ver que la educación comienza en cada uno y que consiste en el paso del ego a la conciencia, no es posible desde la conciencia ordinaria. Este déficit formativo contribuye a que la democracia siga en una fase egocéntrica, y que productos, como el pacto de estado, no sea viable, ni tampoco se considere que se debe ir más allá de un pacto de estado por la educación (Herrán, 2014a, 2016c, 2017c).

- El segundo es que los sistemas sociales en general y los sistemas educativos en particular están alineados, en primer término, con sus propios intereses. Por tanto, no pueden hacer dos cosas: ni educar únicamente, ni educar plenamente. En consecuencia, mientras educan, adoctrinan, 
que es lo más alejado de la educación. Lo hacen nacional, ideológica, cultural, religiosamente, etc. El que 'toda la tribu eduque' es contraproducente, si antes la tribu no se ha destribalizado, es decir, no se ha desidentificado de sus sesgos propios. La tribalización siempre va unida al fanatismo. El par 'tribalización-fanatismo' incide en el sentimiento deformándolo, dese y para el ego personal y/o colectivo. Por eso se siente distinto según le ocurra algo a un afín o a un distante, a un concurrente o a un competidor, en cuyo caso puede aparecer hasta satisfacción con su perjuicio. Por eso, también, unos niños de 5 años que celebran un cumpleaños pueden ser terroristas, un tirano puede ser un ciudadano ejemplar, y lo que beneficia al bien común puede ser sistemáticamente rechazado. Por ello, la presencia de temas radicales como la humanidad, la universalidad o la unidad del ser humano, etc. son estorbos, piedras en el zapato, retos educativos que no encajan con currícula parciales, sesgados, egocéntricos y variablemente afectados de ceguera u obstinación, que son todos. Si el sentimiento está deformado y éste basa y satura la razón, todo producto de la tribu y sus identificados estarán sesgados.

- El tercero es que es que, desde la "teoría de la mora" - desde la que todo sistema se sabe centro de la educación y educador-, parece una anomalía que en cada estado o nación haya un sistema educativo, tal y como hoy se consideran. De la existencia de un sistema educativo, se deduce que los demás sistemas sociales son no educativos, y esta es la incongruencia. Primero, porque todos los sistemas se muestran, enseñan y contribuyen a la educación y a la formación o a la deformación de los demás sistemas e individuos con que interactúan. $Y$ segundo, porque el que los sistemas sociales y personales no sean conscientes de ser 'centros de la educación' -y, por ello, 'sistemas educativos', en sentido estrictoaleja la posibilidad de que la educación comience en ellos, por sí mismos y, como consecuencia, de que cualquier educación sea fiable, radicalmente fundada $y$ se aproxime al ideal de la paideia en el siglo $X X I$. Nuestra respuesta es que este hecho confirma que la educación sólo se entiende externa, periféricamente. $Y$ si algo no se entiende en profundidad, no se comprende.

- El cuarto es que, como la mora tiene un centro y ese centro es quien piensa, imagina, considera, critica o rechaza lo que este fruto representa, el centro de la educación es uno mismo, cada sí mismo. Por tanto, de la teoría de la mora se deduce que la clave de la educación es la educación de quien, consciente o inconscientemente, se pregunta cuál es la clave de la educación. Esto es muy importante. Ahora bien, el centro de uno mismo es su formación. El centro de la formación es su conciencia, en el marco de un estado consciente. El acceso a la conciencia lo da la meditación. La meditación no tiene objetivos, ni contenidos, ni nada, ni no nada. Por tanto, el centro esencial, no tiene nada que ver con la teoría de la mora $y$, a la vez, está intensamente relacionado con ella. La educación centrada en el vacío no nos lo han enseñado. Permanece lejos de lo que la Pedagogía entiende por fin de la educación, por formación o por metodología educativa. Quizá una consecuencia asociable a la ausencia de la teoría de la mora en la educación sea, desde lo anteriormente apuntado, que su asiento principal o que su acceso directo es la meditación, cuya ausencia también contribuye a la exteriorización de la razón y de sus contenidos. 


\section{LA EDUCACIÓN NO SÓLO TRANSCURRE DE LA CUNA A LA TUMBA.}

Esta expresión-que la educación se extiende de la cuna a la tumba- no es sinónimo de educación y aprendizaje durante toda la vida ("long life learning'). Los sistemas educativos modernos se enorgullecen de educar desde los 0 años de edad. Esto, que otrora fue una conquista pedagógica y social, es hoy insuficiente. La educación comienza antes de nacer los padres y, en todo caso, desde la concepción y la fase prenatal de la vida.

De la educación prenatal se han ocupado tradicionalmente las Ciencias de la Salud. Pero, al tratarse de 'educación', en sentido estricto, resulta imprescindible el concurso de la Pedagogía y de las demás Ciencias de la Educación (Herrán, 2015a; Hurtado, Cuadrado y Herrán, 2015b; Herrán, Hurtado y García Sempere, 2018).

Los puntos de vista, los objetos de estudio, los cambios asociados y esperables desde la Pedagogía alcanzarían a la conceptualización, los fines de la educación, los sistemas educativos, la organización escolar, la Didáctica, los programas, las metodologías, incluido el yoga prenatal, la formación de educadores previos a la etapa infantil, la evaluación educativa, la educación de la sociedad, etc. Los beneficios educativos y sociales serían, quizá, inimaginables hoy, a un coste reducidísimo.

La escasa cultura general de carácter pedagógico hace que, de momento, ese proyecto macro se abra camino. El suelo es árido, domina la ignorancia y llueve poco. Aun así, el vector está trazado. Quizá también para esto haya que esperar que otros sistemas pedagógicamente más hechos den el primer paso.

\section{NO SE ESTÁ FORMANDO A EDUCADORES NI A PROFESORES}

Decimos que estamos formando al profesorado. Pero sólo decimos que lo hacemos. Soñamos con que lo hacemos, porque a lo que hacemos lo llamamos 'formación'. Lo que sí se puede constatar mediante la intuición (elaboración desde indicios) es que los profesores se quedan en la superficie de la formación. Una cosa es formar a un profesor y facilitar que se forme y otra preparar surfistas de la educación. $\mathrm{Ni}$ siquiera surfear es nadar ni bucear, con o sin bombona.

Decía en un acto reciente un alto ejecutivo de la educación madrileña que el dilema estaba entre el conocimiento y las competencias, entre el saber y el saber hacer. Es una pena que toda la audiencia aplaudiera, porque la premisa es errónea de entrada: por un lado, las competencias son una clase de conocimientos; por otro, tanto el saber, como el saber hacer, son saberes, obviamente. Por tanto, ninguno de esos pares de términos, por razones distintas, se puede oponer. Lo que quizá quiso decir el político es que el dilema está en preparar profesores 'entendidos' o profesores 'competentes'.

Los dos son exteriores. Son dos estilos de surfeo: el más tradicional y el más moderno. Los dos son periféricos, compatibles, pueden ser factores de un excelente educador, pero ambos desatienden el interior. Por eso no son completos, ni totales, por eso no pueden corresponderse con la formación, sino quizá con otros fenómenos menores de divisiones inferiores, como pueden ser informaciones, capacitaciones, entrenamientos, preparaciones, instrucciones, solvencias... Un dilema es si el sistema 'educativo' debería gravitar en la economía y la sociedad de bienestar y de consumo, o en la "econosuya" (Herrán, 1993) y en la formación. 
Algunas importantes insuficiencias en la formación de los profesores son:

- $\quad$ No se sabe cabal ni profundamente qué es la formación (Herrán y Fortunato, 2018).

- La reflexión aplicada a la práctica no lleva a la formación plena (Herrán, 2011a; Ramírez y Herrán, 2012).

- La atención aplicada a las TICs no conduce a la renovación pedagógica clave (Herrán, 2017e).

- Es tanto o más importante incorporar el estudio y formación en torno a la mala práctica educativa y docente (Herrán, 2016a), junto a la habitual técnico-reflexiva y basada en competencias.

- Si los retos radicales básicos (Herrán, 1993, 1995, 1996) no forman parte de la formación del profesorado, será imposible.

- Es imprescindible incorporar a esa formación el resto de retos y temas radicales (Herrán y Fortunato, 2018).

\section{LA CREATIVIDAD EDUCATIVA NO SE COMPRENDE}

Desde el enfoque radical e inclusivo de la educación, volvemos a percibir lo mismo formalmente cuando se observa la creatividad. Sólo se está viendo una parte de ella -la emergida, la interesante, la de la Pedagogía y la Psicología, la del discurso recurrente o anticreativo- y la fracción radical se desatiende por completo.

La creatividad se aplica a objetos de diferentes clases: a contextos, a condiciones, a posibilidades, a proyectos, a procesos, a productos, a personas, etc. Esa es la creatividad de las definiciones parciales (Herrán, 2006, 2009a, 2010a, 2010b, 2014b), la de los indicadores de Guilford o Torrance, la de las competencias, la de los problemas de las ingenierías, la de la empresa, la de las artes, la de la gastronomía, la de la sexualidad, la de las relaciones interpersonales, las utopías, el saber, el terrorismo, la barbarie,... Eso es creatividad, pero la creatividad no es sólo eso.

Si alguien va a un gimnasio con la expectativa de ejercitar sólo una parte de su cuerpo -por ejemplo, los tríceps braquiales-, la experiencia podrá ser muy satisfactoria, pero, si sólo fortalece esos músculos, se acabará deformando. ¿Qué herbívoro en buen estado de salud, en su fase de cría, se dedica a fortalecer sólo uno de sus lados? Como la naturaleza es autoconsciente, tiende al equilibrio y esto no ocurre. Sin embargo, en el campo de lo humano el entendimiento sesgado y dual es la norma de la educación en general.

La creatividad común es la externa, la de la acción observable y todo lo que la rodea. Esta no discrimina la creatividad educativa. La otra cara de la tela es la interna. Equivaldría a la creatividad del 'crearse', del 'construirse', del 'destruirse', del 'despertar', del 'no crear', del 'sí y no crear a la vez'. En un contexto pedagógico, tendría que ver con la conciencia y su educación, con las raíces que soportan y nutren a la creatividad externa. A la unión entre la creatividad ordinaria y la interior o extraordinaria es a la que denominamos, dentro de la formación "creatividad total” (Herrán, 2000, 2006).

Cualquiera de las dos facetas solas se corresponderá con una creatividad parcial. A una educación somera le sobraría con una educación para la creatividad objetal, que respondería de sobra al enfoque competencial. Una educación plena no se refiere a un creativo competente, sino con un creativo consciente o completo. En el caso de la comunicación o de la investigación educativa, el inicio de este anhelo sería la creatividad externa e interna del educador o del investigador. La de los alumnos, los hijos, los participantes... vendría después. 


\section{LA EDUCACIÓN 'INTER' O} 'TRANS’CULTURALES O NACIONALES SE
QUEDAN A MITAD DE CAMINO

Una vida estructurada conforme al "Yo soy yo y mi circunstancia" de Ortega y Gasset o equivalente, será equívoca -al aludir a cuatro yoes distintos- por ser esencialmente falsa, aunque existencialmente pudiera ser correcta (Herrán, 2004).

Hemos nacido aquí, pero por el aleteo de una mariposa pudiéramos haber nacido en otro lugar, en otro entorno diferente. Por tanto, la circunstancia es el gran factor existencial, pero no es el ser esencial. Análogamente, el vehículo no es su conductor. Sin embargo, si un conductor nunca saliera de su vehículo, acabaría identificado con él.

El ser no tiene nada que ver con su circunstancia. Pero este aprendizaje básico, que tendría que ver con las primeras enseñanzas sobre autoconocimiento- no se enseña en las escuelas. Más bien ocurre lo contrario, porque el centro de gravedad no está en lo esencial, sino en lo existencial y en lo social.

El niño nace universal, y por tanto, no parcial. Paulatinamente, aprende y construye sus significados (conocimientos), vía descubrimiento, recepción, experimentación, repetición, frustración, etc. El resultado es adquisitivo y progresivo. Puede llegar a pensar o a sentir que 'es lo que conoce' -de acuerdo con el "somos lo que conocemos", del maestro González Jiménez (2008)-. Pero esto también es falso esencialmente y verdadero existencialmente. Poco a poco, el niño cree que es su mente, sus contenidos y acciones, y por eso toda su vida puede ser radicalmente desatinada.

Es muy importante diferenciar entre el ser y la añadidura y observar que 'nuestra educación' enfatiza la añadidura sobre el ser esencial, que es un don nadie. Colocar el centro de gravedad de la vida en ella, diferenciarla, distinguirla, distinguirse con ello, creerse distinto por ella, es una forma de programación mental que suele ir acompañada de chantaje, de violencia, de refuerzo y de expectativas manipuladoras y adoctrinadoras. Se logra así hacer creer que el centro de uno está en la capa $X$ de la cebolla. $Y$ no es así.

Como cada ser es universal y único, lo natural sería facilitar algo así como una "educación para el autoconocimiento" (Herrán, 2004; Álvarez y Herrán, 2009), una "educación para la universalidad" (Herrán, 2001, 2008a; Herrán y Ruiz Corbella, 2006; Herrán y Muñoz, 2002) o "para la unidad humana" (Muñoz y Herrán, 2003), y una 'educación para la unicidad'. En lugar de eso, se nos ofrecen 'educaciones' nacionales y nacionalistas o internacionalistas, con base en una atención a la diversidad interpretada dualmente, más en clave de 'hacia sí' que 'desde sí, para la posible evolución de la humanidad.

Desde la razón dual o parcial se suele entender que lo universal y lo singular se oponen. La universalidad es más compleja que la singularidad, como el producto es más complejo que la suma. No hay oposición ni conflicto posible entre ellas. La universalidad o la unidad no confunden: diferencian y realzan, como lo haría una orquesta con sus instrumentos donde, en función de la sinfonía, cabe el solista. La universalidad que no signifique universalidad y singularidad a la vez no es tal, es pseudo universalidad.

Es clave que la universalidad no se condicione, ni manipule. Un riesgo es la totalización de lo parcial, priorización o hipertrofia de una parte sobre el todo, que es ignorado. Este proceder es un artificio, un autoengaño y un perjuicio general a la larga o a la corta. La educación para eso, al no ser natural, requiere de un fuerte condicionamiento, vía adoctrinamiento y tribalización, desde los ismos. Otro riesgo es 
el contrario, la parcialización de lo total, que supedita lo global para el interés y beneficio propio (Herrán, 1997).

En este contexto, lo 'inter' (intercultural, internacional, etc.) y lo 'trans' (transcultural, transnacional, etc.) son desarrollos desde y para lo singular que ignoran lo universal. Lo universal está asociado a la humanidad (Herrán, 2009b). En los currícula suele haber referencias a lo inter y a lo trans. A la humanidad, al sujeto y destino de la universalidad o de la unidad humana, no hay referencia alguna.

"La humanidad es una patria que muere sin haber podido nacer todavía" (Savater, 1997). Sin embargo, a los cuatro años el niño ya puede imaginarse parte de la humanidad (Herrán, 2008a), porque es lo natural, lo universal. Una educación que no anhele la unidad humana, que no tome la humanidad como referencia como han hecho las grandes pedagogías de la historia-, no es educación plena, porque estará teñida de adoctrinamiento tribal y de fanatismo. Podrá ofrecer excelentes resultados en indicadores de evaluaciones de diagnóstico, locales, nacionales o internacionales, pero esos items instructivos no tendrán nada que ver con la educación de la conciencia.

\section{EN ALGUNOS ENTORNOS, LA EDUCACIÓN INCLUSIVA, LA EDUCACIÓN EN VALORES O LA PROPIA EDUCACIÓN PUEDEN SER ESTAFAS}

Es llamativo constatar la existencia de sistemas educativos, centros de enseñanza, aulas o espacios educativos, familias, profesores y padres sexistas, xenófobos, clasistas, autoritarios, Igtbi...fobos, excluyentes, etc. que proclaman, institucional o personalmente, toda clase de 'valores educativos' sociales e individuales biensonantes, como características de su educación. Las apariencias lo aguantan casi todo. Esta opción, que es una norma, es una forma de estafa social generalizada.
Lo mismo ocurre formalmente cuando los centros educativos erigen la bandera de la educación inclusiva, cuando no es así en absoluto (Herrán, 2016c). Generalmente, podría aplicarse la teoría de la estafa a la educación en general. Sería engaño, si hubiera intencionalidad. Pero en la mayor parte de los casos, hay ignorancia, luego no hay fraude.

Estos efectos se producen cuando se comete el "error número 1 de la enseñanza" (Herrán y González, 2002), esto es, rodearse y desatender la propia formación, para hablar, hacer, enseñar, investigar, dirigir, gestionar, etc. a otros. Cuando no se apoya bien el pie en la escalada, los demás elementos y comportamientos serán vanos, aunque aisladamente sean correctos. Por eso, una educación en valores o una educación inclusiva que no se apoye en la conciencia, no es que se haya quedado a mitad de camino, es que no servirá para nada.

La educación, que es única, no se puede apoyar en la apariencia, sino en una formación auténtica y cabal. No es fácil para nadie, pero es un reto ineludible para todo ser consciente y humanizado. Con la palanca bien apoyada en la conciencia, la educación será en valores, en virtudes (Herrán, 2009c), democrática e "inclusiva con sentido" (Rodríguez, 2018, comunicación personal), de un modo automático espontáneo. No será apenas necesario pretenderla. Fluirá como educación orientada a generar personas que vivan en estados más y más conscientes.

\section{BASAR LA EDUCACIÓN EN LA DIVERSIDAD ES UNA INSUFICIENCIA O UN ERROR}

La educación basada en la atención a la diversidad es otro error de enfoque habitual, consensuado y que apenas se cuestiona. Es un error porque la diversidad no es representativa de ningún ser humano. Cada persona no es sólo su diversidad. La diversidad es una faceta del ser, de cualquier contenido del universo y, por ende, de cada persona. Lo que cada ser es 
esencialmente y no es faceta, sino condición, es su unicidad.

Una educación basada en la diversidad gravita en la parcialidad. Ha renunciado a priori a ser una educación basada en la complejidad y en la conciencia. Es una contradicción, si de educación se trata. La persona es mucho más que su diversidad: es 'identidad', 'diversidad', luego 'semejanza', y 'unicidad', con relación a otras personas y los demás seres que componen la existencia. Por tanto, un enfoque con base en la diversidad es limitado y claramente completable, al menos, con un enfoque de identidad, de semejanza y de unicidad pedagógicas.

La atención a la identidad se relaciona directamente con la igualdad ante la ley, pero además atendería a cuestiones comunes esencialmente a todas las personas, con independencia de contextos, épocas, situaciones, características. Algunas de ellas equivaldrían a las 'verdades pedagógicas absolutas' o 'grandes certezas formativas' que posteriormente se referirán.

\section{LO QUE SE ENTIENDE POR EDUCACIÓN INCLUSIVA ES INSUFICIENTE O UN ERROR}

El enfoque radical e inclusivo asegura que sólo nos ocupamos de la superficie de la educación, y que dejamos sin ver, reparar e incluir el interior. Esto es de aplicación, también, a la educación inclusiva, al menos en estos sentidos:

- En que, como se ha visto, la atención a la diversidad en que se apoya es necesaria y a la vez insuficiente, porque reduce la atención educativa a una faceta al ser, que no es sólo diverso.

- En que tanto la integración como la inclusión se interpretan someramente, lo que lleva a conflictos semánticos, déficits de realización profesional e investigaciones educativas mal fundamentadas.
- En que la equiparación de la educación inclusiva a una 'educación para todos sin excepción' es un sinsentido. Sólo la proponen quienes no saben bien de lo que hablan. Por eso, el enfoque radical e inclusivo trabaja por una educación inclusiva no dual, no parcial y "con sentido", propuesto por Rodríguez Herrero (2018, comunicación personal).

- En que es preciso interpretar la educación inclusiva desde la conciencia, y por tanto generar nuevos constructos, como la 'inclusión curricular' que, dentro de la educación inclusiva, pueda reconocer que los currícula habituales o normales no comprenden una dimensión radical, esto es, complementaria a la propia de las asignaturas-competencias específicas y a los temas de carácter transversalcompetencias comunes, compuesta por retos ausentes, excluidos de la educación, inexistentes en los discursos de los organismos internacionales, en los sistemas educativos y en sus currícula, fundamentales para la formación y que no se demandan, sin los cuales la educación, sencillamente, no puede darse plenamente.

- En que, como se describe más adelante, casi todos los que se refieren a la discapacidad de otros tenemos discapacidad, al menos intelectual, verdadera y no sólo nominalmente. Por tanto, real $\mathrm{y}$ fenoménicamente, el panorama es de máxima inclusión. La educación inclusiva es un constructo fabricado para otros por quienes han creído que no tenían especiales dificultades o discapacidades, y que, por tanto, no se han creído lo suficientemente 'diversos'. La realidad no es esta, aunque aún la discapacidad intelectual y afectiva del ser humano no ha sido reconocida como una verdad absoluta, y para nosotros lo es. Por tanto, la educación inclusiva aún está lejos del fenómeno de la inclusión, que, 
si se orienta a una plena normalización, carece de razón de ser fenoménica, aunque tenga una justificación analítica, porque la razón humana necesita apoyos. Todo apunta a que podría llegar a equipararse o a unificarse, por ósmosis inversa de complejidad de conciencia, desde el conocimiento del fenómeno al fenómeno. El día en que se deje de hablar de educación inclusiva por redundante (Herrán, 2015b, 2016c) y se desarrolle desde una educación más consciente de una forma espontánea y natural, habrá iniciado su camino, que no acaba, desde luego, en la inclusión social. Hoy apenas se inicia en la sociedad de la ignorancia, que componemos.

\section{VERDADES ABSOLUTAS O LEYES FORMATIVAS RADICALES}

\section{INTRODUCCIÓN}

El contenido de este parágrafo se deduce y a la vez es causa de todo lo anterior. Su tesis es que hay certezas formativas radicales 0 verdades absolutas en educación y que, por obvias, están al alcance de todos. Convendría que fuesen lo primero que un profesor, un alumno o un investigador tuviesen presentes como referentes contextuales autoformativos externos e internos. De particular tienen que son comunes a casi todos los seres humanos. Por tanto, formarian parte de una 'atención a la identidad' complementaria a la 'atención a la diversidad' con la que casi sólo se identifica nuestra educación. Sin embargo, como ocurre con los demás temas radicales, no se suelen tener en cuenta, aunque su efecto global (exterior e interior) sea muy significativo.

Con frecuencia se llama dogmática a la persona que defiende la existencia de verdades absolutas. Por extensión, se presume que el dogmático quiere imponer su verdad a los demás y manipularla a su antojo. Ante este prejuicio, tres razones, a modo introductorio: la primera es que cuando se defiende esta postura -la supuestamente antidogmática-, se está haciendo lo mismo: respaldar la existencia de una verdad absoluta, aunque en sentido contrario: asegurando que no existe. En este sentido, decía Maurois que: "Es una verdad absoluta que la verdad es relativa". Por otro lado, si se admite que no existen, se está generalizando con poco rigor: se enjuicia sin haber examinado todas y, por tanto, con imprecisión. La tercera es que se suele oponer a las verdades absolutas la alternativa 'democrática', consistente en asegurar que cada uno tiene 'su verdad' sobre lo que percibe, de modo que lo que cada uno interpreta es lo relevante.

Desde el enfoque radical e inclusivo, las tres opciones son egocéntricas y duales, luego son superables dialécticamente. La vía de superación podría ser la objetividad o la descripción de hechos que, en caso de querer hacerlo, podría constatar cualquier persona. Una aplicación y un corolario: el argumento de Maurois, de entrada, es falso porque es absoluto $\mathrm{y}$, según su falso criterio, debería ser relativo. Si lo fuese, su enunciado dependería de contextos, circunstancias, casos, situaciones, etc. Además, es falso porque pueden existir verdades relativas y absolutas a la vez. Einstein se refirió a constantes absolutas en el universo, aludiendo a la velocidad de la luz y a la estupidez humana. Desde la complejidad no rechazamos a priori este testimonio, formulado entre la lucidez, la flexibilidad pedagógica y el sentido del humor, aunque la diferente naturaleza epistemológica de las variables presente problemas de acepción en un mismo plano interpretativo.

Además, ha de tenerse en cuenta el significado del calificativo 'absoluto' y el término 'verdad'. Nos referiremos como 'absolutas' (del lat. absolūtus), de acuerdo con la Real Academia de la Lengua Española (2015) a: "12. f. desus. Aserción universal dicha en tono de seguridad y magisterio", equivalentes a 'concluyentes', 
'generales' y/o 'decisivas'. También: “3. adj. Entero, total, completo" y "6. adj. Fil. Que existe por sí mismo, incondicionado". Y por 'verdad' (del lat. verĭtas, -ātis), nos referimos a las siguientes acepciones: "3. f. Propiedad que tiene una cosa de mantenerse siempre la misma sin mutación alguna", "4. f. Juicio o proposición que no se puede negar racionalmente", "5. f. Cualidad de veraz" y "7. f. Realidad (II existencia real de algo)".

Decía Papini que: "Entre las cosas posibles está también ésta: que existe la verdad y que alguien la posee". Dos cuestiones: la primera es que preferimos hablar de 'verdades', más que de 'verdad', porque nos referiremos a concreciones observables por cualquier persona con capacidad de duda y humildad científica, y nunca a invenciones, trascendentes o no. $Y$ la segunda es que, con certeza, no las poseemos, porque ni la verdad ni las verdades se pueden poseer. Sólo se pueden percibir o deducir, interiorizar y comprender y, en su caso, compartir, como intentamos. La verdad o las verdades poseídas se marchitan desde que se tienen, como las flores recién cortadas.

Las verdades educativas absolutas no son difíciles observar, porque tienen mucho que ver con lo que ocurre en el día a día de la educación, de la sociedad y de la vida. Al observarse durante muchos años, se consideran observaciones fiables. Como se ha dicho, son verdades objetivas, apoyadas en fenómenos: puede ser observadas y experimentadas por cualquier persona consciente. Desde luego, no somos los primeros en verlas, pero sí estamos empeñados en relacionarlas con la Pedagogía, la educación, la enseñanza y la formación, intentando superar la dualidad entre lo básico y lo inédito.

Al ser absolutas -es decir, decisivas, generales y concluyentes-, en ellas se podría apoyar con seguridad el compás de la educación y de la propia formación, para trazar la curvatura más consciente y firmemente. De otro modo y más allá: sin apoyarse en ellas, el resultado puede ser -suele ser- una figura desnaturalizada, mal hecha que no hace posible la educación plena.

Desde el enfoque en que trabajamos, son objetivas y evidentes -como los demás temas y retos radicales-, como lo es el hecho de que la respiración oxigena la sangre. Lo que nos resulta objetiva, evidente y paradójicamente extraño es que, por ejemplo, no estén incluidas en los currícula, en la educación y en la formación; que los organismos internacionales de educación no busquen su normalización vía complejidad de conciencia; que los fines de la educación no se relacionen con ellas; que desde nuestra educación no se vean como certezas en las que apoyar una 'educación derivada de la atención basada en la identidad' -del todo complementaria a nuestra 'educación derivada de la atención basada en la diversidad'- $y$, desde ella, una pedagogía del autoconocimiento, si bien, preliminar, no del todo profunda. Como ocurre con muchos objetos que tratamos, quizá su extensión, su saturación, impide la toma de conciencia aplicada. Es como el pez que busca el océano nadando en él: no lo ve, porque está demasiado cerca de él, no es capaz de distanciarse, no medita y no puede observarlo. Otra cuestión es su alta educatividad, en tanto que definidoras y orientadoras.

Por otro lado, no hay inconveniente epistemológico ni didáctico en equiparar las siguientes certezas a leyes educativas, a leyes de conciencia. Con el mismo espíritu de firmeza que los fines de la educación, pero con una mirada de anhelo profundo o radical (aplicándoselo todo primero a uno mismo), nos identificamos con la siguiente acepción de 'ley' (del lat. lex, legis) de la Real Academia de la Lengua Española (2015): "Regla fija a la que está sometido un fenómeno de la naturaleza". La entendemos válida, en la medida en que la educación y la formación se consideran fenómenos de la naturaleza. 
En consecuencia, se proponen algunas verdades absolutas o certezas formativas radicales estrechamente relacionadas entre sí, con cuya inclusión en la educación se avanzaría extraordinariamente. Son de aplicación general, a excepción de los budas o personas completamente despiertas, que apenas han existido en la historia del ser humano:

\section{SOMOS TEMPORALES, MORTALES $Y$ FINITOS O LEY FORMATIVA DE LA CONCIENCIA DE MUERTE Y FINITUD:}

Somos seres mortales y limitados en todos los sentidos. Esta es la condición necesaria para otorgar a la vida un sentido, que puede ser egocéntrico o consciente. En cualquier caso, el ser humano no es un ser para la muerte, sino para la trascendencia. Las muertes forman parte de la evolución e importan al ser humano. En consecuencia, la conciencia de muerte y de finitud debería formar parte de la formación y de la educación de un modo natural. No se trata de agrandarlas con una lupa, sino de que, como parte de la vida y de cualquier enseñanza, se incluya como factor clave de la formación. Esto sólo se puede hacer desde y para la conciencia, esto es, no de un modo tangencial, marginal o desde la cuasi exclusión curricular, como es lo habitual.

Hay una muy escasa presencia de la conciencia de muerte y de finitud en el discurso de los organismos internacionales de educación, de los sistemas educativos y sus currícula y de los proyectos institucionales de los centros educativos de todas las edades. Salvo contadas excepciones, tampoco forma parte de la formación inicial o continua de los profesores. Hay disposiciones hacia la muerte que lo explican, según domine la indiferencia, el tabú o la educatividad. Se trata de favorecer el paso de la muerte de tabú a imperativo educativo (Herrán, González, Navarro, Freire y Bravo, 2001), comenzando por la elaboración, vía interiorización, de la propia muerte (Herrán y Cortina, 2006).

\section{SOMOS IGNORANTES O LEY FORMATIVA DE LA CONCIENCIA DE IGNORANCIA:}

Es muy importante que los seres humanos sean conscientes de su predominante ignorancia. Todos somos ignorantes, aunque cueste verlo, de un modo parecido a como la materia es, sobre todo, vacío y no lo parece. Maestros del bien común como Siddhartha Gautama en Oriente o Sócrates en Occidente repararon en este fenómeno. Un paradigma ilustrativo de este hecho es Newton (1686), quien escribió: "Conocemos una gota, desconocemos un océano". También Einstein (1980) reparó en ello.

Algunos piensan que su gota es un océano. Puede creerse lo que se quiera sobre esto: dependerá de si se razona con la inteligencia de un microorganismo que no ha tomado conciencia de la gota en que vive o de un ser humano lúcido. Pero la creencia no cambia el fenómeno. Se reconozca o no, todo compartimos esta condición de ignorantes, si bien unos son conscientes de ello y otros lo ignoran y lo niegan.

Con esta perspectiva, la diferencia entre un sabio y un inculto puede ser pequeña, si el sabio que no es maestro es ignorante con relación a su conciencia, y esto es posible. Análogamente, es relativamente pequeña la diferencia entre genomas de especies diferentes, de modo que los fenotipos y la epigenética no tienen nada que ver. En este marco, los saberes pueden jugar un papel a la vez insignificante y parcialmente relevante. En ningún caso jugarán un papel muy relevante, en cuanto a la formación radical, porque ésta no sólo no se limita a ellos. La educación como fenómeno los trasciende encuadrándolos en su preciso lugar, esto es, como una parte o como una fase de ella. 
La ciencia sí admite la duda y la conciencia de ignorancia aplicada al saber como requisitos de la investigación, tanto hacia su propia línea de investigación como hacia otros ámbitos y objetos de estudio. La primera es la base del proceso investigador, que comienza con la conciencia de lo que se desconoce y con el diseño de investigación orientado a la solución de ese problema cognoscitivo. Sobre la segunda, Fernández-Rañada dijo: "Los científicos saben hoy más que nunca de sus propias especialidades, progresivamente más estrechas, pero ignoran también mucho más de lo que saben sus colegas". Al formar parte del discurso científico normal, la conciencia de ignorancia del científico permanece ligada a la acción profesional y a la preparación para ella y, por tanto, alejada de la personalidad. Al permanecer en un estrato superficial del papel y la función del científico, normalmente no alcanza al ego. En el caso de los profesores y de los alumnos, la conciencia de ignorancia es algo más delicada porque, aunque se trate de un hecho objetivo, unos y otros se pueden dar por aludidos, sentirse heridos y tomárselo como algo personal, cuando no es así.

A medida que el estudiante o el joven aprenden, conocen y se adentran en la adultez y en la vejez, puede experimentar otra clase de ignorancia. La podemos denominar 'ignorancia subyacente'. Es contextual e interna, profunda, de carácter permanente y resistente al conocimiento y los saberes. Es como una infección a la que los antibióticos ya no le hacen efecto. Uno mismo, por mor de su ego, no la suele ver, pero en algunos momentos de la vida se manifiesta como problema (auto)formativo relevante causado por una desorientación educativa esencial. Lo explica Osho (2013):

Según vas haciéndote mayor, pierdes la sensibilidad para el asombro, te vas embotando más y más. Pero la razón de ello es que ahora lo sabes todo. No sabes nada, pero ahora tu mente está llena de conocimientos cogidos de aquí y allá, y ni siquiera has pensado que debajo de todo eso no hay más que oscuridad e ignorancia... (p. 29).

No es nada nuevo. En el Tao Te Ching, Lao Tse (2006) dice: "Cuanto más lejos se va, menos se comprende". El sentido es el mismo. El significado fundamental es que la superación de la ignorancia no sólo depende del aprendizaje o de la adquisición de conocimientos. Un acervo de conocimientos desconectado de la conciencia no equivale a verdadera formación. Es sólo educación aparente. Análogamente, saber cómo conducir no conlleva una buena conducción: conducir bien no es saber acelerar, frenar y mover el volante o conocer las señales, es mucho más. Se requiere conciencia. Análogamente, nuestra educación confunde superficie y profundidad formativa, porque desconoce la segunda por completo. Por eso bajo un vasto conocimiento puede haber inconsciencia, infelicidad, confusión y sentimiento de vacío existencial. Es posible ser diez veces doctor/a y haberse quedado a mitad del camino formativo.

La ignorancia no es el problema. El problema es la ignorancia de la ignorancia, y la coexistencia formativa de esta inopia, tanto en el día a día como en proyectos elaborados. Este es un importante reto radical de la educación para cuya visión y comprensión es preciso distanciarse, para la mutación del Homo sapiens sapiens al Homo sapiens ignorans.

\section{SOMOS INMADUROS O LEY FORMATIVA DE LA CONCIENCIA DE INMADUREZ GENERALIZADA:}

El egocentrismo humano lastra y confunde a la conciencia. Es el epicentro de la inmadurez adulta y, junto con la ignorancia, el origen de todos los errores del ser humano. Es la molécula que mantiene rota y descompuesta a la humanidad y la principal fuente que impide que la formación ola 
educación de las personas puedan evolucionar. El ser humano es egocéntrico durante toda la vida. El egocentrismo no es específico de ninguna edad ni se supera nunca, normalmente. "Pocos seres humanos maduran" (Osho, 2014, p. 196). Si algún calificativo tiene esta sociedad es el de sociedad 'del egocentrismo' o 'de la inmadurez'. De hecho, grandes cantidades de adultos responden a un patrón adolescente (Rojas, 1990) o preoperatorio (Herrán, 2008a, 2008b, 2014).

El enfoque pedagógico que tiene en cuenta el ego humano data de maestros como Siddhartha Gautama, Bodhidharma, Nagarjuna o Dogen zenji, Maharsi, Krishnamurti, Osho, etc., que, en épocas distintas, han coincidido en lo esencial. En palabras de uno de ellos, Ryûju, o Nagarjuna: "Si queréis ver la naturaleza de Buda, debéis primero eliminar vuestro propio egoísmo" (en Dogen Zenjí, 2013, p. 131). "Ver la naturaleza de Buda" es despertar, hacerse conscientes. La consideración del ego humano como factor clave a tener en cuenta para la educación es algo habitual en la educación clásica de Oriente. En Occidente, en tanto que tema radical, apenas se percibe o se considera relevante en la educación. Eso sí, con excepciones. En su "Ensayo sobre la ceguera", Saramago (2001) escribe: "En verdad aún está por nacer el primer humano desprovisto de esa segunda piel que llamamos egoísmo". Lo mejor de esta cita es la alusión al egoísmo asociada al ser humano. Pero no es precisa, por un doble motivo: porque al nacer no hay egoísmo, y porque, si se piensa en el adulto, hay quien se deshace de esa segunda piel, como hacen los reptiles al crecer o la mariposa al salir del capullo: son muy pocos, se han llamado 'budas' (despiertos), y quizá no haya habido más de diez en la historia de la humanidad.

Su coincidencia verifica el "Todo lo que se eleva, converge”, de Teilhard de Chardin. Ante esta evidencia, coincidente en lo esencial y verificada civilización tras civilización, siglo tras siglo hasta la actualidad, ¿qué ha hecho la educación? ¿Y la Pedagogía? La respuesta es no, por cuatro razones: por la amplitud del problema -que hace que la figura se confunda con el fondo-, porque compone la normalidad, porque, desde un punto de vista pedagógico, es un tema radical, y porque los seguidores de estos maestros normalmente han deteriorado sus enseñanzas.

\section{ESTAMOS ENFERMOS POR EL EGO O LEY FORMATIVA DE LA CONCIENCIA DE LA ENFERMEDAD DEL EGO:}

Está estrechamente relacionado con lo anterior. El ser humano padece 'la enfermedad del ego'. El problema al que nos referimos no es sintetizable en que nuestra sociedad está patologizada (Montero, 2018). Quizá pudiera decirse, figurativamente, que la educación 'tiene mala salud' (Herrán, 2017f). Pero esta afección fundamental no está relacionada con la salud: no es una enfermedad médica, psiquiátrica o psicológica; no es un tema de la Psiquiatría o de la Psicología: es un padecimiento educativo general que debe ser estudiada intensamente por la Pedagogía. El estudio afectaría a los directivos, docentes, alumnos de todas las edades, investigadores, sistemas y agentes educativos sociales, etc.

Al ser un reto radical, aunque para algunos sea asintomático, tiene tantos síntomas que no se reconocen. Es lógico que, por su generalidad, no se distinga bien. A esta verdad objetiva le ocurre lo que a las demás: al afectar a cada ser humano, que convive con otros a los que les pasa lo mismo, no se advierte. Es como el olor a contaminación que se respira: acaba por no notarse. Por eso no está camuflada ni tapada: es general y descarada, y afecta a la práctica totalidad de personas y sistemas sociales. La enfermedad del ego tiene que ver con la propia formación y, desde ella, con la propia razón, con algo parecido a un "síndrome egótico", que se refracta en "conocimientos sesgados" (Herrán, 
1997) y con la educación de cada individuo y de la sociedad. El ego no sólo es personal: también es colectivo. Secundariamente, pudiera estar relacionado con lo que se entiende por problemas de salud psíquica, que sí serían objetos de estudio de la Psicología y la Psiquiatría.

La enfermedad educativa que comentamos coadyuva a la articulación de los procesos en torno al propio ego (Herrán, 1997; Osho, 2004). O sea, a sí y para sí, al propio interés, a lo entendido como afín o como propio, a lo mío, a mí, mis, a creerse diverso, distinto, mejor que los demás, a la dificultad para la autocrítica y rectificación, al darse por aludido, sentirse herido, a la dualidad, parcialidad, identificación y sesgo en la razón, etc.

Que afecte al ser humano significa que es una característica de la vida de la persona en todos sus momentos evolutivos: en el bebé, en el estadio preoperatorio, en la niñez, en la adolescencia, en la juventud, en la adultez... El ego es el factor más importante de la inmadurez, que tiende a continuar toda la vida. Además, el ego es la fuente más importante de errores del ser humano. Cuando la enfermedad formativa del ego se apodera de una persona o de un colectivo, no es tanto que se comentan errores egógenos, es que la vida se desarrolla sobre los rieles del error. La vida centrada en el ego garantiza la mediocridad humana y es incompatible con la educación de los demás. De ahí la relevancia de tener este factor (de) formativo en la formación de educadores: padres, profesores, sistemas sociales, etc.

Hemos calificado a la nuestra como sociedad del egocentrismo. La solución no es 'adaptarse' a una sociedad enferma, en este sentido. Como apunta Krishnamurti: "No es saludable estar bien adaptado a una sociedad profundamente enferma". El antídoto o la curación de esta enfermedad pedagógica tendría que ver con una (auto)formación o educación basada en la conciencia, la duda, la humildad, en saberse un ser normal y corriente, falible, finito y mortal, ignorante, estúpido en grado variable; en la salida de las propias cavernas, la universalidad, el desprendimiento, el descondicionamiento, la diferenciación entre lo existencial y lo esencial, la meditación, el amor, etc.

\section{SOMOS MIOPES O LEY FORMATIVA DE LA CONCIENCIA DE MIOPÍA:}

Ya hemos hecho alguna alusión a este fenómeno. La miopía oftalmológica es el defecto de la visión causado por la incapacidad del cristalino de enfocar objetos lejanos. Se corrige con lentes o con una intervención con láser. La miopía a la que nos referimos no se refiere al ojo, sino a la conciencia, en tanto que órgano de la visión. Es, en efecto, un problema de enfoque producido por el ego. Por tanto, está muy relacionada con la 'enfermedad del ego'.

El fenómeno está -como los demás- muy generalizado. Todos somos miopes. Vemos poco, y mejor lo de cerca. Nos cuesta construir una conciencia distanciada e integrar en ella a los demás. La mirada corta se aplica al propio ombligo o a los satélites que orbitan en torno a sí. La fuerza de gravedad que dinamiza el sistema es el egoísmo y el egocentrismo. Teniendo en cuenta que "La persona crece inversamente al egoísmo", la miopía tiene que ver con la inmadurez y con la mala formación, porque no ha trascendido los límites y condicionantes del ego.

Es propia de niños y también de adultos poco y mal educados. No importa que sean éxitos 'educativos' del sistema: si son egocéntricos/ as, todo lo que hagan estará globalmente mal. Como están obnubilados, corren el riesgo de tropezarse o caerse a alcantarillas sin tapa. Es el ego lo que exacerba la visión de lo inmediato. La miopía es egógena. Repara en todo lo propio: personas, interés, rentabilidad, afinidades, etc. Las articulaciones de sus movimientos son la dualidad, la parcialidad. El miope no es 
un buen observador, porque muchas de sus interpretaciones están sesgadas. En su campo visual tampoco cabe el verdadero amor, que desconoce experimentalmente. En la medida en que el opuesto al egocentrismo es ese amor, la miopía podría corregirse con lentes de ese material o con láseres de esa clase de luz coherente. Otra vía pedagógica es la meditación.

\section{ESTAMOS DORMIDOS O LEY FORMATIVA DE LA CONCIENCIA DE INCONSCIENCIA:}

En cuanto a conciencia o vida consciente se refiere, estamos dormidos, amodorrados, narcotizados. No sólo obnubilan el fútbol o las religiones, sino el propio conocimiento. Dicho de otro modo: somos seres inconscientes, aletargados, nuestra razón está casi permanentemente aturdida, entumecida, incluso hipnotizada. Algunos autores han descrito este hecho: desde Siddhartha Gautama (Buda, 1997; Osho, 2007; Rawding, 1991; Shearer, 1993), Marti (1961, 1965), James (1907), Maharshi (1986, 1987), Jung (1983), Krishnamurti (1981, 1983, 2008), Osho (2013, 2014a, 2014b), Caballero (1979), Mello (1987a, 1987b), etc. Sus tesis son altamente coincidentes, se validan mutuamente. Uno de los más didácticos fue el pedagogo José Martí (1961), que dijo:

La mayor parte de los hombres ha pasado [su vida] dormida sobre la tierra. Comieron y bebieron; pero no supieron de sí. La cruzada se ha de emprender ahora para revelar a los hombres su propia naturaleza, y para darles, con el conocimiento de la ciencia llana y práctica, la independencia personal que fortalece la bondad y fomenta el decoro y el orgullo de ser criatura amable y cosa viviente en el magno universo ( $p$. 99).

Que el constructo y el fenómeno de la conciencia o de la educación para una vida consciente estén tan lejos de la educación y del currículo no ayuda mucho a avanzar en este sentido educativo. $\mathrm{Ni}$ la educación, ni la Pedagogía afrontan clara y directamente este fenómeno, ni siquiera entendido como posibilidad, porque de momento lo entienden escasamente. En consecuencia, ni los investigadores ni los educadores dudan, se preguntan, planifican, desarrollan, evalúan, etc. una eventualidad equivalente, comenzando por la propia formación. Por eso, un tema radical e inadvertido es la enseñanza para la formación de los maestros del bien común, cuyo fin básico y común era despertar, abrir la conciencia, no programar ni adoctrinar. ¿Qué grado, postgrado o acción de formación continua de docentes de cualquier nivel de enseñanza, de pedagogos o de psicopedagogos estudia, una vez 'descondicionada' -algo así intentó Vives con la obra de Aristóteles-, la enseñanza para la formación de clásicos como Krishna, Lao Tse, Gautama Buda, Bodhidharma, Mahavira, Kung zi, Zhuang zi, Lie Yukou, Yeshua; de contemporáneos, como Maharsi, Blay, Krishnamurti, Osho, etc., o la sabiduría ancestral de otras culturas y chamanes de pueblos indígenas originarios? Siendo los despertadores de la humanidad, los 'cracks' de la educación, los Messis, Ronaldos o Casillas de la formación, ¿cómo es posible que no se consideren relevantes? Una explicación es la ausencia en el corpus de la Pedagogía de constructos o herramientas esenciales para su inclusión (conciencia, ego, muerte, universalidad, autoconocimiento, etc.).

¿Tiene sentido formativo la exclusión de quienes han atravesado el río de la educación de uno a otro lado, desde el sueño al estado consciente? En una educación de tercera división como la nuestra, articulada en conceptos/fenómenos básicos y secundarios a la vez, como el aprendizaje, el conocimiento, la curiosidad, la pregunta, etc., es lógico que se eludan. La Pedagogía del ego, del despertar, del estado consciente, de la universalidad, del amor, etc. juega en otra división. Nuestra conclusión es que, si de educación se trata, jugar en tercera o 
en enésima división es perder todos los partidos. Es un poco como en el mus, en donde se dice: "Jugador de chica, perdedor de mus". O sea, si se apuesta a chica, casi siempre se pierde. Esto es, un poco, lo que nuestra educación está haciendo.

\section{SOMOS BASTANTE ESTÚPIDOS O LEY FORMATIVA DE LA CONCIENCIA DE ESTULTICIA:}

Si estupidez es estulticia, engreimiento, idiotez, vanagloria o tiesura, ocurrirá como con la ignorancia o como con el egocentrismo o la inmadurez: que habrá que reconocer que todos tenemos un algo o un mucho de estupidez, y que este hecho debería ser relevante para cualquier consideración o acción educativa. Ahora bien, al ser un fenómeno predominante y estar tan expandido, tiende a negarse y a pasar desapercibido, porque forma parte de la normalidad del día a día. Reconocerlo puede coadyuvara tomárselo personal, neuróticamente, $y$ al dolor de una herida narcisista.

Pero la realidad es que no se libra casi nadie. La estupidez merece una consideración pedagógica (Rodríguez, 2018). Einstein (1980) aludió a la estupidez humana como una de las constantes absolutas en el universo. Cuando lo hizo, pensó en adultos, no en niños. Al hilo de ello, podemos preguntarnos, con Dumas, cómo pueden ser tan inteligentes los niños y tan estúpidos los adultos, $y$, sobre todo, por qué, para suponer que esta intuición es posiblemente verdadera. ¿Acaso la 'educación' y la experiencia adquiridas tendrían algo que ver con ello? Afirmamos que sí, porque su desarrollo se ha orientado a:

- Preparar personas aptas para dejarse llevar, para ser convencidas, seducidas y conducidas por otros o 'programadas', en sentido estricto (Herrán, 2014b, p. 38). Este 'dejarse llevar' es acorde con el concepto de estulticia o de estupidez de Séneca (2012) (Carta XXXVI a Lucilio, en Gómez Ramos,
2014), de Erasmo de Rotterdam (1999) o de Einstein (1980).

- Convencer a las personas conducidas y programadas de que lo deseable es existir en determinadas cavernas, nuevos senos maternos o ismos (políticos, nacionales, culturales, religiosos, científicos, etc.), evidentemente más acertados o superiores a los demás, teniendo en cuenta que todos piensan y sienten lo mismo.

- Eludir la búsqueda del conocimiento con base en la conciencia y otorgar relevancia democrática relativa a las creencias, a las opiniones, a los intereses articulados sobre prejuicios compartidos, para evitar que se incrementa la simpleza y la tontada, porque "el prejuicio es la razón de los tontos" (Voltaire, 1892).

- Preparar personas aptas o competentes para ser buenos profesionales, y no profesionales conscientes $\mathrm{o}$ personas interiorizadas y formadas.

- Aprender durante toda la vida, como perfeccionamiento profesional y personal desde más y más saberes, y no, quizá, a tomar conciencia de que por ese camino crecerá poco como ser humano consciente.

Una de las claves para dejar de ser engreídos e idiotas es darse cuenta de ello. Lo dice el clásico Zhuang zi (1999): "Saberse idiota es ya no ser tan idiota". Hasta los mayores éxitos de nuestro sistema educativo -podrían ser los catedráticos/ as de universidad con decenas de JCRs en Q1-, que a priori son las personas más sabias e instruidas en sus materias, pueden haberse formado mal, escoradamente. Educativamente serán un fracaso y un peligro, si por dentro hubiesen sido devorados por su ego. De hecho, la mayoría son luchadores y sabios. Pero una pequeña parte son egocéntricos, engreídos, idiotas, en sentido estricto, además de buenos 
cortadores (procústeos) de las alas de otros. En estos casos, son pencos -según la Real Academia de la Lengua Española (2015): “3. m. Persona inútil"-, seres inútiles, autoinvalidadas para la educación. Su mayor contribución a la formación es ser indicadores de calidad de que la nuestra formación no está bien orientada, ni es eficaz para el despertar de la conciencia. La educación es la evolución del ego al estado consciente de cada uno. Cuando la estulticia, que es un lastre, desaparece, emerge la humildad y el anhelo de educación de la razón, que es un primer paso para formarse más allá del ego.

\section{TENEMOS DISCAPACIDAD INTELECTUAL O LEY FORMATIVA DE LA CONCIENCIA DE DISCAPACIDAD INTELECTUAL GENERAL:}

No es infrecuente escuchar aquello de que 'todos tenemos discapacidad intelectual', seguido de una sonrisa falsaria. Casi siempre los ponentes lo dicen para quedar bien, para hacerse los inclusivos. Suele ser, bien una afirmación aparente, gratuita, bien una pose ficticia que no nos creemos, bien la intuición de un hecho. Lo más gracioso -por lo de lla sonrisa- es que es cierto y que se puede objetivar y demostrar por qué, cómo y cuándo.

Nuestra posición afirma que todos tenemos discapacidad intelectual. No es una postura, sino un hecho clarificable y que se reconocerá científicamente cuando se investigue. Las causas -que pueden incidir como factores- más importantes que intervienen en la discapacidad intelectual de todo ser humano son tres: la incidencia del ego en la razón, la escasa o limitada complejidad de conciencia aplicable, y la inconsciencia, que puede aplicarse a todas las 'verdades absolutas' revisadas, incluyendo ésta. Las tres fuentes definen la 'conciencia ordinaria', al amparo de la que se ejercita esta forma de discapacidad.
La consecuencia es que, habitualmente, se razona mal. Por 'razonar' se entiende 'usar la razón'. Nuestra acepción de 'razón' se acoge a la acepción empleada en la Grecia clásica y que actualiza González Jiménez (2008). Esto es, la razón es lo que existencialmente somos -"somos nuestra razón”, "lo que se educa es la razón"-, incluyendo todas las formas de conocimientos (significados), sesgados o no.

Algunos de sus indicadores son los que siguen -se da prioridad, con carácter hipotético, a la descripción significativa sobre la exhaustividad y el no solapamiento, toda vez que el constructo 'discapacidad intelectual no reconocida' o 'd. i. de quienes creen que no tienen discapacidad intelectual' está pendiente de investigación empírica:

- Rasgos distintivos: dualidad, egocentrismo, parcialidad, sesgo, dependencia, miopía, interpretación fragmentaria (pars pro toto), etc.

- Confusiones características: entre lo existencial y lo esencial, entre lo superficial y lo profundo, entre lo generado por el ego y por la conciencia, entre lo real y lo imaginado o inventado, etc.

- Elementos constituyentes: preeminencia de conocimientos sesgados y sesgables: sentimientos, actitudes, ideas, creencias, conceptos, procedimientos o destrezas, opiniones, predisposiciones, prejuicios, generalizaciones falsas, opiniones, adoctrinamientos, fanatismos en grado variable, reflexiones, deliberaciones, juicios, valores, competencias, etc.

- Elementos coadyuvantes: la inmadurez social general, la sociedad del egocentrismo, la educación superficial o sesgada, la creciente insensibilidad, la ausencia de duda, de autocrítica, la codicia, el bajo nivel cultural, los confesionalismos, etc. 
- Inercias: desde y para el ego personal y colectivo, las ubres de turno, el culto a la normalidad, las propias cavernas, los programas personales o sociales, las certezas, las seguridades, la acumulación, el miedo a la pérdida, la influencia, la consideración, el sentimiento diferencial personal o colectivo, creerse extraordinario, mejor, etc.

- Dificultades asociadas: para la duda, para la humildad, para ser normal y corriente, para la autocrítica, para la rectificación, para la renuncia, para la pérdida consciente, para el destete o el abandono de las ubres, úteros, cavernas, ismos, autores, ideologías, religiones, convicciones, sesgos, dualidades, parcialidades, para las síntesis, para una razón que sea parte de un estado consciente, para la ética, para el autoconocimiento, para la serenidad, para el vacío, etc.

\section{SOMOS PACÍFICOS Y BÁRBAROS A LA VEZ O LEY FORMATIVA DE LA CONCIENCIA DE PAZ-BARBARIE:}

\section{El conflictoola pazexternos einternos son efectos} del equilibrio o desequilibrio social y personal. La sociedad y sus miembros, normalmente, se desarrollan desde el desequilibrio a un equilibrio que se anhela y al que la naturaleza contribuye. En esa inestabilidad dinámica basan su desarrollo que, como si fuese un río -por el problema energético lo motiva-, no puede parar. Ahora bien, cuando la paz interna es una paz profunda, no hay ni desequilibrios ni dinámicas: sólo quietud y silencio, no ser. De esto se deduce que:

- Cualquier planteamiento de educación para la paz con base en la dinámica humana, atiende a una lectura de paz externa o interna, comportamental, tanto aplicable a personas como a sistemas sociales.
- Si el punto de apoyo de la palanca del progreso es el desequilibrio, el factor que lo satura es el ego humano, no la conciencia o la vida consciente -que estarían más cerca de la paz como quietud-.

- El ego es fuente de conflicto, de dificultades de aprendizaje y de formación; obtura la evolución posible desde el condicionamiento dual. Esto lleva a pensar qué es lo opuesto a la paz externa, y, por tanto, si no sería más útil, dadas la circunstancia (sociedad del egocentrismo), poner la atención en los obstáculos, los lastres y los cabos que impiden que el globo aerostático de la educación se eleve en conciencia o que la paz interna se descubra.

- Lapazprofundaoexperienciaautoconsciente de vacío es el estadio más evolucionado de la (auto)educación para la paz. Además, es un tema formativo radical. Por tanto, tiene cierto sentido el recorrido: ego - paz externa e interna - paz profunda. El camino que conduce a ella es la meditación.

La paz es una expresión básica de amor. Lo opuesto al amor es el egocentrismo. Lo opuesto a la paz es la barbarie, que implica un gran desequilibrio egógeno y que puede entenderse como cualidad inherente al ser humano. La barbarie, como la paz, pueden ser efectos sociales reconocibles. Pero también son cualidades humanas que definen a todos, al menos, como pacíficos y como bárbaros en potencia. La clave es la formación y la circunstancia. Con relación a la barbarie, en especial las consecuencias, la impunidad. Por ejemplo, en la película "La redada" Ilama la atención la eficacia con que algunos gendarmes franceses se hicieron crueles, la rapidez de los cambios de mentalidad, la barbarie latente. Este fenómeno se da desde la infancia. Lo hemos sentido, su fuego no está del todo apagado en casi nadie. Sólo unos pocos lo extinguen por completo. Una misma persona es paz y 
barbarie, sabio y malo a la vez. Otra cosa es que la interpretación no invierta las tornas: la relatividad de los puntos de vista puede llevar a entender que un sabio es vil para unos y virtuoso para otros. Tiene que ver con el ego interpretativo. Parece que la violencia está asociada al sexo y al género masculinos, por razones sociales y/o genéticas, a juzgar por los porcentajes de encarcelados por violencias de todo tipo.

Lo anterior es del máximo interés, porque está relacionado con la supervivencia personal. Pero su importancia se acrecienta cuando de lo que se trata es de la supervivencia social, porque la barbarie afecta a un/a dirigente o líder de masas. La formación en ego y conciencia del dirigente es un tema pedagógico radical de suma importancia. Tomando como referencia el pasado, volvemos a insistir (Herrán, 2003) en la necesidad de arbitrar una medida universal, complementaria a la formativa, avalada por un organismo internacional (ONU) para que todo dirigente político o religioso deba someterse y superar una evaluación psiquiátrica anti barbarie como requisito de elegibilidad democrática. Antes de las ideologías y doctrinas está la necesidad de que la cotización de una vida humana no baje hasta niveles ínfimos o negativos: deseo de muerte del otro o el diferente, asesinatos masivos, genocidios, etc., por causa de una mente perturbada. La historia es un escaparate suficiente.

Como conclusión, la educación para la paz se pueda abordar de tres maneras no excluyentes: atendiendo a la educación para la paz externa, tanto personal como social, que es el enfoque actual; atendiendo la paz interna -que puede ser profunda-, directamente, desde la meditación, y trabajando la barbarie interna y externa, desde la educación del egocentrismo, junto a todas las certezas formativas anteriores, tanto individual como socialmente.

\section{COROLARIOS}

Algunos posibles corolarios de estas posibles certezas formativas:

- Considerarse o referirse a cualquier ser humano como finito, ignorante, inmaduro, dormido, estúpido, enfermo, con discapacidad intelectual, etc. no debería ofender a nadie. Es como entender que somos primates: es un hecho zoológico, una descripción. Desde una indagación pedagógica pueden ser, además, referentes formativos con base en la identidad. La diversidad se mostraría, por ejemplo, con los grados: desde los más inconscientes hasta los budas. Si a alguien le molesta que le llamen ignorante, dormido o persona con discapacidad, si se da por aludido o se siente herido, es que tiene pendiente algo por hacer con su enfermedad educativa. De ahí el daño, la dolencia, que la indica.

- Quien esto escribe ha compartido lo anterior en contextos de formación inicial y continua de profesorado de todos los niveles de enseñanza, en reiteradas ocasiones. Lo que se observa, normalmente, es que una mayoría de participantes experimenta una profunda satisfacción cuando toma conciencia de ello. Diríase que, inmediata y superficialmente, resulta extraño. Pero, en un segundo momento se entiende como algo reconocido y natural. Normalmente, la falta de rutas neurológicas aplicadas de los participantes se traduce en una atención absorta seguida de la creación de un "estado de conciencia compartido" (Herrán, 1998a) de duración variable. Posteriormente, ya tratando contenidos técnicos o de otra naturaleza, lo relativo a estas 'certezas' se relega, pero siguen presente. Ocurre como las raíces de una planta, que, desde su no ser, están presentes en el tejido del ser. Al cabo de los meses, aquel contenido se recuerda por muchos. Estadísticamente, 
también es detestado por otros, que deben tener porquería en la nariz, porque otras cosas también les huelen mal.

\section{A MODO DE CONCLUSIÓN}

Hablar de qué estamos haciendo mal en la educación es hablar de errores. Hay errores superficiales, medios y profundos o radicales. Los radicales (ausencias en el diagnóstico, presencias con las que se pierde, huecos inéditos, insuficiencias limitantes, alternativas ausentes, etc.) son los menos evidentes para investigadores, profesionales y usuarios. Sin embargo, son los que asocian impactos o refracciones más abundantes y graves. De hecho, las raíces son en cualquier zona del árbol de la educación o de la persona, pero en menor medida es al revés.

De otro modo: los errores radicales no son propios de aquello a lo que afectan. Por tanto, el problema que asocian no es que se cometan. Esto es sólo su apariencia. El problema real, complejo y consciente es que coadyuvan a que casi todo lo que se haga -o se deje de hacerpueda estar mal interpretado, alcanzando a los fines y la orientación de la educación, al modo de organizarse en sistemas educativos, al contenido e intenciones del currículo, a la formación del profesorado, a su enfoque evaluativo, al modo de entender su investigación, etc.

En estos días se confirman dos hechos relevantes de amplio espectro. Uno es de trascendencia universal y otro, de alcance filogenético o evolutivo. Como son asuntos radicales, ninguno ha sido recogido por medios de comunicación.

El primero es que vamos en un camarote del Titanic. Si no ganamos en visión (prismáticos, radar...), nos acompaña una muerte cercana. Por desgracia, vamos a toda máquina sin norte y sin conciencia suficiente. El segundo es que se acredita que el eslabón perdido entre el simio y el ser humano maduro y consciente, que todavía no ha nacido, somos nosotros. Los dos pueden ser orientadores de nuestra desorientación esencial como humanidad y como especie. Es posible que lo que hagamos individual y socialmente tenga un sentido. Pero, "desde un punto de vista ecológico amplio, el ser humano no sabe lo que está haciendo" (Bateson, 1977). Es lo esperable, puesto que seguimos dormidos, en cuanto a conciencia se refiere.

Estamos en un callejón sin salida aparente. Pero un viejo proverbio chino dice que: "Todo callejón sin salida, tiene una salida". Desde nuestra perspectiva radical e inclusiva, que va al origen de la causa, la alternativa es nuestra educación, la de cada uno de nosotros: es el principio del hilo, no hay otro a la vista. Otras opciones tienen carácter complementario. Dicho de otro modo, el trabajo más propiamente educativo queda por hacer, y no es externo ni ajeno a nosotros.

Desde lo expuesto, ¿cuál habría de ser la principal función de la Pedagogía? No puede ser continuar su camino como ciencia sin conciencia, ni fundamentar la continuidad y el desarrollo de una educación necesaria e insuficiente que promueve y apuntala. La primera función de la Pedagogía es ayudar a ver al ser humano, comenzando por los educadores, investigadores de la educación y pedagogos, en el sentido amplio y preciso de Touriñán (2018), para que puedan desarrollar un camino más complejo y consciente. Después, la ciencia de la educación por antonomasia podría acicatear y acompañar a otros en su camino formativo, como en su día hicieron los primeros pedagogos griegos con los hijos de los romanos acomodados.

La función de la Pedagogía radical e inclusiva es insistir en varias posibilidades: que la educación tiene todo que ver con cada ser y con cada sistema social y sociedad que se compone, y no sólo con el sistema educativo; que lo que llamamos educación, no lo es en absoluto; que los organismos internacionales de educación, los sistemas educativos, los fines de 
la educación, la sociedad en general y la propia Pedagogía están radicalmente equivocados en cuanto a la educación y la formación se refiere: no la entienden, y este hecho ni se sabe ni se reconoce -lo que es tan grave como si una Medicina que no curase completamente nunca lo reconociese-. Tampoco responde a un diagnóstico social y pedagógico profundo, no se identifican insuficiencias, ni se desarrollan alternativas con base en la conciencia.

El proceso de cambio radical a que apuntamos podría sintetizarse en tres vectores:

- En educación, en el paso del enfoque competencial al enfoque consciente, que lo engloba -no ocurre al revés-.

- En investigación educativa, en el paso de productos científicos bien elaborados a productos de conciencia, que podrían englobarlos -depende del tema y el problema de investigación-. La investigación educativa científica se identifica hoy con la investigación empírica, cuantitativa o/y cualitativa. Los objetos de estudio de la Pedagogía requieren, además, investigación hermenéutica, reflexiva, centrada en la conciencia, etc. De otro modo, el conocimiento construido estará sesgado.

- Tanto en educación como en investigación, en la formación radical e inclusiva de educadores, formadores e investigadores de educación.

La educación radical e inclusiva comprende, pero trasciende, la reflexión focalizada en el alumno y en la práctica docente, en el currículo, las necesidades sociales y profesionales demandadas, la mejora de la educación y la mejora social, tal y como habitualmente se entienden. Fundamenta el salto de una educación basada en el aprendizaje y el conocimiento a una educación basada en la conciencia, que incluya, necesariamente, pedagogías para la eliminación y la pérdida de lo proveniente del ego humano, para el autoconocimiento, la meditación, la universalidad y la humanidad, el despertar de la conciencia, etc., como contenidos de fines claves de la educación. Para ello recurre a la complementariedad, la destrucción (refutación) y la construcción de una educación renovada pedagógicamente con temas radicales, cuyo fin común sea favorecer un estado más consciente de cada individuo consciente -en particular, padres, profesores, alumnos, políticos, medios $y$ todos los sistemas sociales, incluidos los educativos-, orientado a saberse educandos, educadores y sujetos objetos de su propia formación.

Tras este recorrido, deducimos que el título de esta aportación es, realmente, absurdo: ni la educación es un juego, ni conocemos todas las cartas, ni sabemos jugar bien, ni el Titanic existe ya. Lo esencial de la metáfora es dejar de vivir en camarotes o cavernas egocéntricas. La salida posible no tiene nada que ver con sentimientos o emociones. La educación no es para los valientes, es para los conscientes que han despertado.

\section{REFERENCIAS}

- Álvarez, N. y Herrán, A. de la (2009). Claves del autoconocimiento. Camagüey: Ácana.

- Bateson, G. (1977). Vers une écologie de I'esprit (vol. I). Paris: Éditions du Seuil.

- Buda (1997). Dhammapada o las enseñanzas de Buda. México: FCE.

- Caballero, N. (1979). El camino de la libertad (vol. I: Una sociedad de sonámbulos satisfechos) ( $4^{\mathrm{a}} \mathrm{ed}$.). Valencia: EDICEP.

- Chisholm, L., Larson, A. and Mossoux, A.-F. (2004). Lifelong Learning: citizens' views in close-up. CEDEFOP: Luxembourg. 
- Colardyn, D. \& Bjørnåvold, J. (2005). The learning continuity: European inventory on validating non-formal and informal learning National policies and practices in validating non-formal and informal learning. CEDEFOP: Luxembourg.

- Condorcet (1922). Escritos pedagógicos. Madrid: Colección Universal.

- Condorcet (1980). Bosquejo de un cuadro histórico de los progresos del espíritu humano. Madrid: Editora Nacional.

- Confucio (1969). Los cuatro libros de Confucio. Madrid: Bergua.

- Deshimaru, T. (1981). El cuenco y el bastón. 120 cuentos zen. Barcelona: Visión Libros.

- Dogen Zenjí, E. (2013). Shobogenzo. Madrid: Sirio.

- Einstein, A. (1980). Mi visión del mundo. Barcelona: Tusquets.

- Erasmo de Rotterdam (1999). Elogio de la locura. Madrid: Espasa.

- García Flores, A. B. (2017). Lorca se despide de su amada Residencia de Estudiantes. RTVE. Noticias. Cultura (15/06/2017). Recuperado de: http://www. rtve.es/noticias/20170615/lorca-se-despidesu-amada-residencia-estudiantes/1565182. $\underline{\text { shtml }}$

- Gómez Ramos, A. (2014). La paradoja de la estupidez. Espaco pedagógico, 21(1),61-79

- González Jiménez, F. E. (2008). Qué es y de qué se ocupa la Didáctica: Sus fundamentos y métodos. En A. de la Herrán Gascón, y J. Paredes (Coords.), Didáctica General. La práctica de la enseñanza en educación infantil, primaria y secundaria (pp. 1-26). Madrid: Mc Graw-Hill Interamericana.
- Herradas, S. (2017). En el aula... ¿meditación o mindfulness? En A. de la Herrán Gascón (Coord.). Meditación y educación. Boletín del Ilustre Colegio Oficial de Doctores y Licenciados en Filosofía y Letras y en Ciencias de Madrid. Apuntes de Pedagogía (269), 14-16. Recuperado de https://www.cdlmadrid.org/wp-content/ uploads/2017/01/062017.pdf

- Herrán, A. de la (1993). La educación del siglo XXI. Cambio y evolución humana. Madrid: Ciencia 3.

- Herrán, A. de la (1996). Hacia otra nueva educación. Boletín del Ilustre Colegio Oficial de Doctores y Licenciados en Filosofía y Letras y en Ciencias de Madrid (75), 24-25.

- Herrán, A. de la (1997). El ego humano. Madrid: San Pablo.

- Herrán, A. de la (1998a). La conciencia humana. Madrid: San Pablo.

- Herrán, A. de la (1998b). La Duda como Principio de Enseñanza. Tendencias Pedagógicas (Número Extraordinario), 109118.

- Herrán, A. de la (2000). Hacia una creatividad total. Arte, individuo y sociedad (12), 71-89. Recuperado de http://revistas. ucm.es/index.php/ARIS/article/viewFile/ ARIS0000110071A/5921

- Herrán, A. de la (2001). El derecho a la universalidad: un desafío educativo para el siglo XXI. Tarbiya: Revista de investigación e innovación educativa (27), 57-74. Recuperado de https://revistas.uam.es/ tarbiya/article/view/7315/7641

- Herrán, A. de la (2002). Educación para la Universalidad: Más Allá de lo Intercultural. Revista creatividad y sociedad (2), 25-32. Recuperado de http://radicaleinclusiva.com/ 
wp-content/uploads/2018/01/masallaint.pdf

- Herrán, A. de la (2003). El siglo de la educación. Formación evolucionista para el cambio social. Huelva: Hergué.

- Herrán, A. de la (2004a). El autoconocimiento como eje de la formación. Revista Complutense de Educación, 15 (1), 1150. Recuperado de https://revistas.ucm. es/index.php/RCED/article/viewFile/ RCED0404120011A/16270

- Herrán, A. de la (2004b). Nacionalismos y educación para la universalidad. Revista Complutense de Educación, 15 (2), 383-430. Recuperado de http://revistas. ucm.es/index.php/RCED/article/view/ RCED0404220383A/16141

- Herrán, A. de la (2006). Hacia una creatividad complejo-evolucionista. Redefinición del concepto de creatividad desde una educación de la conciencia. En S. de la Torre, y V. Violant (Coords.), Comprender y evaluar la creatividad. Un recurso para mejorar la calidad de la enseñanza. Málaga: Aljibe.

- Herrán, A. de la (2008a). Hacia una educación para la universalidad: más allá de los ismos. En J. Valle (Coord.). De la identidad local a la ciudadanía universal: el gran reto de la educación contemporánea (pp. 209-257). Bilbao: Fundación para la Libertad-UAM. Recuperado de http:// radicaleinclusiva.com/wp-content/ uploads/2018/01/haciaunaeduniv.pdf

- Herrán, A. de la (2008b). ¿Valores en una sociedad adolescente? Retos de una educación diferente. Revista IberoAmericana de Estudos em Educação, 3 (1, 2), 71-84. Recuperado de https://dialnet. unirioja.es/servlet/articulo?codigo $=6203067$

- Herrán, A. de la (2009a). Contribución al concepto de creatividad: un enfoque paquidérmico ( $1^{\mathrm{a}}$ parte). Educación $y$ Futuro. Revista de Investigación Aplicada y Experiencias Educativas (21), 43-70. Recuperado de https://dialnet.unirioja.es/ descarga/articulo/3235596.pdf

- Herrán, A. de la (2009b). Educación de la humanidad: El reto de una nueva Pedagogía. En M. Almendro (Coord.), Krisis. Vitoria: Ediciones La Llave.

- Herrán, A. de la (2009c). ¿De la educación en valores sociales a la educación en virtudes humanas?, en C. Vilanou, Á. Casado, A. de la Herrán, y L. Grosso, La educación: un arte extasiológico (pp. 59-94). Madrid: Fundación Fernando Rielo.

- Herrán, A. de la (2010a). Contribución al concepto de creatividad: un enfoque paquidérmico ( $2^{\mathrm{a}}$ parte). Educación $y$ Futuro. Revista de Investigación Aplicada y Experiencias Educativas (22), 151-175. Recuperado de https://dialnet.unirioja.es/ descarga/articulo/3216505.pdf

- Herrán, A. de la (2010b). Contribución al concepto de creatividad: un enfoque paquidérmico ( $3^{a}$ parte). Educación $y$ Futuro. Revista de Investigación Aplicada y Experiencias Educativas (23), 131-162. Recuperado de https://dialnet.unirioja.es/ descarga/articulo/3313512.pdf

- Herrán, A. de la (2011a). ¿Más allá del profesor reflexivo y de la reflexión sobre la práctica? En A. Medina, A. de la Herrán y C. Sánchez (Coords.). Formación pedagógica y práctica del profesorado (pp. 117-152). Madrid: Ramón Areces. Recuperado de http://radicaleinclusiva.com/wp-content/ uploads/2018/01/masallaprofreflex.pdf

- Herrán, A. de la (2011b). La madurez institucional como constructo pedagógico. 
En E. Sebastián Heredero y M. Martin Bris, Transferencia del conocimiento a partir de prácticas educativas en los contextos español y brasileño (pp. 145-163). Alcalá de Henares: Universidad de Alcalá.

- Herrán, A. de la (2011c). Indicadores de madurez institucional. Revista Iberoamericana de Estudos em Educaçao, 6 (1), 51-88. Recuperado de http://seer.fclar. unesp.br/iberoamericana/article/view/4799

- Herrán, A. de la (2011d). Reflexiones para una reforma profunda de la educación, desde un enfoque basado en la complejidad, la universalidad y la conciencia. Educación XX1 (14), 245-264. Recuperado de http:// revistas.uned.es/index.php/educacionXX1/ article/view/271/227

- Herrán, A. de la (2012). Currículo y pedagogías innovadoras en la Edad Antigua. REICE. Revista Iberoamericana sobre Calidad, Eficacia y Cambio en Educación 10 (4), 286-334. Recuperado de http://www. rinace.net/reice/numeros/arts/vol10num4/ art17.htm

- Herrán, A. de la (2013). Reflexiones sobre el cambio del cambio en Pedagogía. Un enfoque radical. Matices del Posgrado Aragón. Universidad Nacional Autónoma de México (20), 5-24 Recuperado de http://radicaleinclusiva.com/wp-content/ uploads/2018/01/cambpedagradical.pdf

- Herrán, A. de la (2014a). Enfoque radical e inclusivo de la formación. REICE. Revista Iberoamericana sobre Calidad, Eficacia y Cambio en Educación, 12 (2), 163-264. Recuperado de: http://www.rinace.net/reice/ numeros/arts/vol12num2/art8.pdf

- Herrán, A. de la (2014b). Creatividad y formación radical e inclusiva: cuando la creatividad no sirve para nada. Granada: Editorial Universidad de Granada.
Fundación José Luis Tejada. Recuperado de http://issuu.com/pablogarciasempere/ docs/creatividad_y_formacion_radical_e i

- Herrán, A. de la (2015a). Educación prenatal y Pedagogía prenatal. Revista Iberoamericana de Educación, 69 (1), 9-37. Recuperado de http://www.rieoei.org/ deloslectores/7195.pdf

- Herrán, A. de la (2015b). La educación inclusiva como redundancia. Boletín del Ilustre Colegio Oficial de Doctores y Licenciados en Filosofía y Letras y en Ciencias de Madrid. Apuntes de Pedagogía (255), 14-16. Recuperado de https://www. cdlmadrid.org/archivos/062015.pdf

- Herrán, A. de la (2015c). ¿El niño como maestro? En J. L. Villena Higueras y E. Molina Fernández, Ciudades con vida: Infancia, participación y movilidad (pp. 103108). Barcelona: Graó. Recuperado de http://radicaleinclusiva.com/textos/

- Herrán, A. de la (2016a). La mala práctica educativa desde el enfoque radical de la formación. Boletín del Ilustre Colegio Oficial de Doctores y Licenciados en Filosofía y Letras y en Ciencias de Madrid (267), 1012. Recuperado de http://radicaleinclusiva. com/wp-content/uploads/2018/01/ malapracticaedu.pdf

- Herrán, A. de la (2016b). Más allá de la atención a la diversidad en educación: educación basada en la conciencia de la unicidad. En M. Antón Antón, J. Bellver Izquierdo, J. García Cortés e I. S. Segura García (Coords.), Educar amb emoció. Valencia: Generalitat Valenciana. Conselleria D’Educació, Investigació, Cultura i Esport. Cefires De La Comunitat Valenciana.

- Herrán, A. de la (2016c). Reflexiones pedagógicas desde el enfoque radical e inclusivo de la formación. Salamanca: 
Fahrenhouse. Recuperado de http://www. fahrenhouse.com/omp/index.php/fh/catalog/ book/24

- Herrán, A. de la (2017a). ¿Y si nuestra educación estuviese radicalmente equivocada? En A. Medina, A. de la Herrán Gascón y M. C. Domínguez (Coords.), Nuevas perspectivas en la formación de profesores. Madrid: UNED. Recuperado de http://radicaleinclusiva.com/textos/

- Herrán, A. de la (2017b). Para una Pedagogía radical e inclusiva. Editorial Revista Virtual Redipe (7), 24-32. Recuperado de http:// revista.redipe.org/index.php/1/article/ view/276/0

- Herrán, A. de la (2017c-1). Pedagogía radical e inclusiva. Primera parte: Problemas radicales de la educación y la formación. En A. de la Herrán, M. C. Domínguez Garrido, R. Ferreiro Gravié, M. Medina Domínguez y A. Medina Rivilla, Hacia una Didáctica del siglo XXI. Zapopan (Jalisco): Editorial Universidad Santander (UNISAN). Recuperado de http://radicaleinclusiva.com/ wp-content/uploads/2018/09/Pedagogia radical_e inclusiva_i_Introduccion_e insuficiencias.pdf

- Herrán, A. de la (2017c-2). Pedagogía radical e inclusiva. Segunda parte: Alternativas radicales de la educación y la formación. En A. de la Herrán, M. C. Domínguez Garrido, R. Ferreiro Gravié, M. Medina Domínguez y A. Medina Rivilla, Hacia una Didáctica del siglo XXI. Zapopan (Jalisco): Editorial Universidad Santander (UNISAN). Recuperado de http://radicaleinclusiva.com/ wp-content/uploads/2018/09/Pedagogia radical e inclusiva II Alternativas.pdf

- Herrán, A. de la (2017d). Sin meditación no hay educación. Boletín del Ilustre Colegio Oficial de Doctores y Licenciados en
Filosofía y Letras y el Ciencias de Madrid. Apuntes de Pedagogía (269), 24-26. Recuperado de https://www.cdlmadrid.org/ wp-content/uploads/2017/01/062017.pdf

- Herrán, A. de la (2017e). La clave de la educación no está en las nuevas tecnologías de la información y la comunicación. Acta Scientiarum Education, 39 (3), 311-317. Doi: http://dx.doi.org/10.4025/actascieduc. v39i3.33008

- Herrán, A. de la (2017f). Por qué nuestra educación tiene mala salud. Observaciones desde el enfoque radical e inclusivo de la formación. En M. J. Miranda Velasco (Coord.), Seminario Internacional Escuelas Promotoras de Salud y Objetivos de Desarrollo Sostenible. Investigación, Políticas, Currículum y Competencias para la Acción (18 y 19 de diciembre de 2017). Cáceres: Universidad de Extremadura. Grupo de Investigación Innovación en Educación y Salud (GIIES) (SEJ033).

- Herrán, A. de la (2018a). Fundamentos para una Pedagogía del saber y del no saber. São Paulo: Edições Hipótese. Recuperado de https://drive.google.com/ file/d/1dprFjWeqkKkOMS-AxCCZpe_UqU$\underline{64 U n Q / v i e w}$

- Herrán, A. de la (2018b). La Pedagogía ante el adoctrinamiento de las religiones. Conjectura: filosofia e educação (23, n. especial, dossiê Educação, Ética e Religião), 2-58. DOI: http://dx.doi. org/10.18226/21784612.v23.especial.1

- Herrán, A. de la y Álvarez, N. (2010). Para qué enseñar: significado y sentido de la formación universitaria. En J. Paredes y A. de la Herrán (Coords.), Cómo enseñar en el aula universitaria (pp. 59-74). Madrid: Pirámide. 
- Herrán, A. de la y Cortina, M. (2006). La muerte y su didáctica. Manual para educación infantil, primaria y secundaria. Madrid: Universitas.

- Herrán, A. de la y Cortina, M. (2007a). Fundamentos para una Pedagogía de la muerte. Revista iberoamericana de educación, 41 (2), 1-12. Recuperado de https://dialnet.unirioja.es/servlet/articulo?co digo $=2195496 \&$ orden $=98072 \&$ info=link

- Herrán, A. de la y Cortina, M. (2007b). Introducción a una Pedagogía de la muerte. Revista educación y futuro. Revista de investigación aplicada y experiencias educativas (17), 131-148.

- Herrán, A. de la y Cortina, M. (2007c). Introducción a una Pedagogía de la muerte. Contexto \& educaçao. revista do programa de pós-graduaçao em educaçao nas ciencias (78), 215-235.

- Herrán, A. de la y Cortina, M. (2008). La educación para la muerte como ámbito formativo: más allá del duelo. Psicooncología (5), 409-424. Monográfico: "afrontamiento del sufrimiento y la muerte". Recuperado de https://revistas.ucm.es/index.php/PSIC/ article/viewFile/PSIC0808220409A/15442

- Herrán, A. de la y Cortina, M. (2009). La muerte y su enseñanza. Diálogo filosófico. Monográfico dedicado a la muerte (75), 499516. Recuperado de http://radicaleinclusiva. com/wp-content/uploads/2018/01/ lamuerteysuensenanza.pdf

- Herrán, A. de la y Fortunato, I. (2018). ¿Por qué desde la Didáctica no se favorece la formación del profesorado? Pro-Posições (29) [en edición]. Recuperado de https:// www.fe.unicamp.br/publicacoes/periodicos/ pro-posicoes

- Herrán, A. de la y González, I. (2002). El ego docente, punto ciego de la enseñanza, el desarrollo profesional y la formación del profesorado. Madrid: Universitas.

- Herrán, A. de la y González, I. (2003a). La educación para la muerte: selección de propuestas. Aula de infantil (12), 14-18.

- Herrán, A. de la y González, I. (2003b). L'educació per a la mort a l'etapa infantil. Selecció de propostes. Guix d'infantil (12), 14-18.

- Herrán, A. de la y González, I. (2004). Selección de propuestas metodológicas para la educación para la muerte. Revista digital de formación del profesorado del CAP "San Lorenzo de El Escorial" (Tema del mes) (4), 1-5. Recuperado de http://centros5. cnice.mecd.es/capescorial/tema\%202.htm

- Herrán, A. de la y González, I. (2005). La educación para la vida-muerte: del tabú al proyecto educativo de una escuela infantil. En M. del C. Prada, D. Madrid, M. Barrales y C. Ruiz (Coords.), Evaluación e intervención psicopedagógica y social en educación infantil. Málaga: Grupo "Educación infantil y formación de educadores".

- Herrán, A. de la y Muñoz, J. (2002). Educación para la universalidad. Más allá de la globalización. Madrid: Dilex.

- Herrán, A. de la y Paredes, J. (2008). Didáctica general: la práctica de la enseñanza en educación infantil, primaria y secundaria. Madrid: Mc Graw-Hill.

- Herrán, A. de la y Ruiz Corbella, M. (2006) (Coords.). Educación de lo local a lo global. Boletín del Ilustre Colegio Oficial de Doctores y Licenciados en Filosofía y Letras y en Ciencias de Madrid. Apuntes de Pedagogía (174), 13-29. 
- Herrán, A. de la, González, I., Navarro, M. J., Freire, M. V. y Bravo, S. (1998). La educación para la muerte como tema transversal de transversales. IV Congreso Mundial Educación Infantil. Madrid, 4-8 de diciembre. Recuperado de http://www. waece.org/biblioteca/pdfs/d052.pdf

- Herrán, A. de la, González, I., Navarro, M. J., Freire, M. V. y Bravo, S. (1999). La muerte, un tabú en la educación. Escuela española (3410), 17-18.

- Herrán, A. de la, González, I., Navarro, M. J., Freire, M. V. y Bravo, S. (2000). ¿Todos los caracoles se mueren siempre? Como tratar la muerte en educación infantil. Madrid: Ediciones de la Torre.

- Herrán, A. de la, González, I., Navarro, M. J., Freire, M. V. y Bravo, S. (2001). La muerte: ¿tabú o imperativo educativo? Aula de innovación educativa (106), 62-64.

- Herrán, A. de la, González, I., Navarro, M. J., Freire, M. V. y Bravo, S. (2002). ¿Cómo educar para la muerte? Un andamiaje. Cuadernos de Pedagogía (310), 22-25.

- Herrán, A. de la, González, I., Navarro, M. J., Freire, M. V. y Bravo, S. (2004). La educación sobre la muerte en la etapa infantil. selección de propuestas. En M. Anton Rosera y B. Moll Ferre, Educación infantil. Orientaciones y recursos (0-6 años). Barcelona: CISS-Praxis.

- Herrán, A. de la, y Muñoz Diez, J. (2002). Educación para la universalidad. Más allá de la globalización. Madrid: Dilex.

- Hurtado, M., Cuadrado, S. y Herrán, A. de la (2015). Hacia una Pedagogía Prenatal. Una Propuesta Educativa. Revista Iberoamericana de Educación (67/1), 151168. Recuperado de https://rieoei.org/ historico/deloslectores/6809Hurtado.pdf
- James, W. (1907). The energies of man. New York: Scribners.

- Jung, C. G. (1983). La psicología de la transferencia. Barcelona: Paidós Ibérica.

- Kant, I. (1989). Crítica de la razón pura (6 ed.). Madrid: Alfaguara (e.o.: 1978).

- Krishnamurti, J. (1981). Can Brain Be Totally Free? http://www.youtube.com/ watch?v=2PAmyOKaAkE (4 Jun. 2013).

- Krishnamurti, J. (1983). Educando al educador. México: Editorial Orión (e.o.: 1953).

- Krishnamurti, J. (2008). Aprender es vivir. Cartas a las escuelas. Madrid: Gaia.

- Lao Tse (2006). Tao te ching. Los libros del tao. Madrid: Trotta.

- Machado, A. (2008). Campos de Castilla. Madrid: Cátedra.

- Martí, J. (1961). Ideario pedagógico. La Habana (Cuba): Imprenta Nacional de Cuba.

- Medel, C. (2003). Lifelong learning discourses in Europe. Hamburg: UNESCO. Institute for Education. http://unesdoc. unesco.org/images/0013/001364/136413e. pdf

- Mello, A. de (1987a). La iluminación es la espiritualidad. Curso completo de autorrealización interior. Vida nueva (1590-91), 27-66. Recuperado de https://salvablog01.files.wordpress. com/2015/11/01-de-mello-anthony-lailuminacic3b3n-es-la-espiritualidad.pdf

- Mello, A. de (1987b). El canto del pájaro. Santander: Sal Terrae.

- Montero, R. (2018). Hipersensibles. El país, 21 de octubre. Recuperado de https://elpais.com/elpais/2018/10/15/ 
eps/1539631976 933706.html

- Montessori, M. (2013). El niño. El secreto de la infancia (e.o.: 1982). México: Diana.

- Muñoz Diez, J. y Herrán, A. de la (2003). Educación para la unidad humana: una alternativa a la crisis mundial. Loja (Ecuador): UTPL.

- Newton, I. (1686). Philosophiæ naturalis principia mathematica. Cambridge: University of Cambridge.

- Osho (2004). El libro del ego. Liberarse de la ilusión. Barcelona: Grijalbo.

- Osho (2007). Buda. Su vida y enseñanzas. Madrid: Océano-Gaia.

- Osho (2013). El peligro de la verdad. Desaprender para conocerte. Barcelona: Debolsillo.

- Osho (2014). El libro de la comprensión. Trazando tu propio camino hacia la libertad. Barcelona: Debolsillo (e.o.: 2006).

- Platón (1969). Apología de Sókrates. Madrid: Bergua.

- Ramírez Vallejo, M. S. y de la Herrán, A. (2012). La madurez personal en el desarrollo profesional del docente. REICE. Revista Iberoamericana sobre Calidad, Eficacia y Cambio en Educación, 10(3), 2544. Recuperado de http://www.rinace.net/ reice/numeros/arts/vol10num3/art2.pdf

- Rawding, F. W. (1991). Buda. Madrid: Akal (e.o.: 1975).

- Rodríguez, I. (2018). Claves para educar. Estupidez humana. Recuperado de https://isabelrodriguezclavesparaeducar. com/2018/07/27/estupidez-humana/

- Rojas, E. (1990). Indicadores de madurez de la personalidad. Cuadernos Empresa y
Humanismo (23), 1-13.

- Rousseau, J.J. (1987). Emilio o de la educación. Madrid: EDAF.

- Saramago, J. (2001). Ensayo sobre la ceguera. Madrid: Alfaguara.

- Savater, F. (1997). El valor de educar. México: Ediciones del Instituto de Estudios Educativos y Sindicales de América.

- Séneca (2012). Cartas a Lucilio. Barcelona: Juventud.

- Shearer, A. (1993). Buda: Un corazón inteligente. Madrid: Debate.

- Touriñán, J. M. (2018b). Imagen social de la Pedagogía (disciplina científica y carrera). Revista Boletín Redipe, 7(9), 32-58.

- Valle, J. y Toribio, L. (2008). El pacto escolar: La necesidad de un consenso nacional en materia de educación (Págs. 23-46). Madrid: Fundación para Libertad-UAM.

- Voltaire (1892). Obras completas. Valencia: M. Senent.

- Vygotski, L.S. (1978). El desarrollo de los procesos psicológicos superiores. Madrid: Crítica

- Zhuang zi (1999). Zhuang zi: maestro Chuang tse. Barcelona: Kairós. 